Florida International University FIU Digital Commons

$3-27-2013$

\title{
The Japanese History Textbook Controversy Amid Post-War Sino-Japanese Relations
}

Maria Gabriela Romeu

Florida International University, mrome012@fiu.edu

DOI: $10.25148 /$ etd.FI13042304

Follow this and additional works at: https://digitalcommons.fiu.edu/etd

Part of the East Asian Languages and Societies Commons

\section{Recommended Citation}

Romeu, Maria Gabriela, "The Japanese History Textbook Controversy Amid Post-War Sino-Japanese Relations" (2013). FIU Electronic Theses and Dissertations. 849.

https://digitalcommons.fiu.edu/etd/849

This work is brought to you for free and open access by the University Graduate School at FIU Digital Commons. It has been accepted for inclusion in FIU Electronic Theses and Dissertations by an authorized administrator of FIU Digital Commons. For more information, please contact dcc@fiu.edu. 


\title{
FLORIDA INTERNATIONAL UNIVERSITY
}

Miami, Florida

\section{THE JAPANESE HISTORY TEXTBOOK CONTROVERSY AMID POST-WAR SINO-JAPANESE RELATIONS}

\author{
A thesis submitted in partial fulfillment of \\ the requirements for the degree of \\ MASTER OF ARTS \\ in \\ ASIAN STUDIES \\ by
}

Maria Gabriela Romeu 
To: Dean Kenneth G. Furton

College of Arts and Sciences

This thesis, written by Maria Gabriela Romeu, and entitled The Japanese History Textbook Controversy Amid Post-War Sino-Japanese Relations, having been approved in respect to style and intellectual content, is referred to you for judgment.

We have read this thesis and recommend that it be approved.

Paul Kowert

Matthew Marr

Steven Heine, Major Professor

Date of Defense: March 27, 2013

The thesis of Maria Gabriela Romeu is approved.

Dean Kenneth G. Furton

College of Arts and Sciences

Dean Lakshmi N. Reddi

University Graduate School

Florida International University, 2013 


\section{DEDICATION}

I dedicate this work to my friend, Omar Carrion, who sadly and tragically left this world before I finished. I hope that your passion for Japan can live through me as you watch from the other side. 


\section{ACKNOWLEDGMENTS}

My entire committee's guidance and support was instrumental in my completion of this thesis. My major advisor, Dr. Steven Heine, deserves tremendous gratitude; thank you for always supporting my work, having patience with me, and believing in my abilities. I would also like to thank Dr. Paul Kowert for not only his kindness and support, but also his advice, insight, and helpful feedback. Finally, I would like to thank Dr. Matthew Marr, for his support in the form of helpful articles and his detailed feedback and corrections. Thank you for all being encouraging and patient with me, and for not minding all of my emails concerning deadlines. I would also like to give a special thanks to my wonderful family, friends, loved ones, and Asian Studies/SIPA

coworkers. Thank you all for your moral support, for the endless words of encouragement, and for always wishing me the best. 
ABSTRACT OF THE THESIS

THE JAPANESE HISTORY TEXTBOOK CONTROVERY AMID POST-WAR SINOJAPANESE RELATIONS

\author{
by \\ Maria Gabriela Romeu \\ Florida International University, 2013 \\ Miami, Florida

\section{Professor Steven Heine, Major Professor}

The relations between China and Japan are strained and continue to foster negative emotions partly because of China's grievances about Japan's actions during World War II and the allegedly false historiographical accounts found in Japanese history textbooks. This study will utilize historical analysis of the events leading up to the Nanjing Massacre in December of 1937, examine the Japanese Ministry of Education's (MEXT) critical and contentious role in the selection of textbooks, used for primary and secondary schools, and will also juxtapose the controversial 2001 Atarashii rekishi kyōkasho with current Japanese history textbooks. The study will also include a syntactical analysis of key terms through my own original translations of multiple Japanese history textbooks, which are currently used in the Japanese school curriculum, to reveal that the textbook publishers, MEXT, and regulation councils are involved in adjusting the content causing the information to reveal various degrees of whitewashing. 


\section{TABLE OF CONTENTS}

CHAPTER

PAGE

\section{INTRODUCTION}

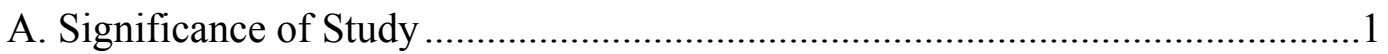

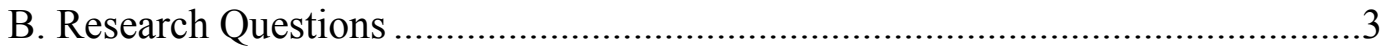

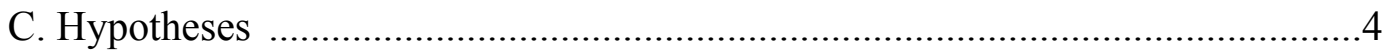

D. Methodology ........................................................................................ 5

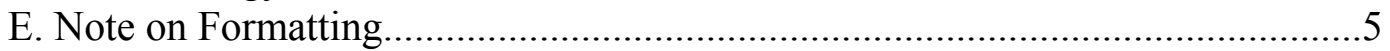

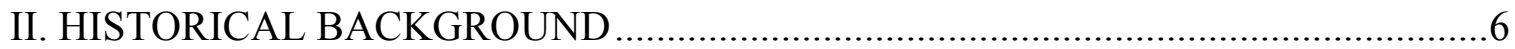

A. Atrocities during World War II and the Second Sino-Japanese War ................6

B. Ienaga Saburō and the Beginning of the Textbook Controversy .....................23

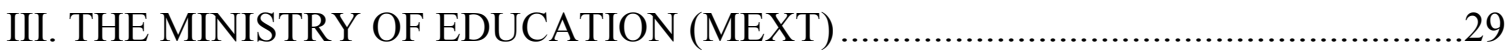

A. The Textbook Selection Process ....................................................................29

B. MEXT, Tsukurukai, and the 2001 Atarashii rekishi kyōkasho ........................33

IV. 2012 JAPANESE MIDDLE SCHOOL HISTORY TEXTBOOKS ..........................51

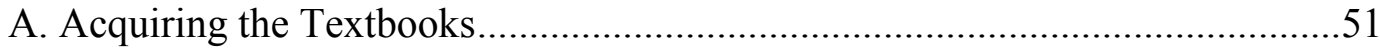

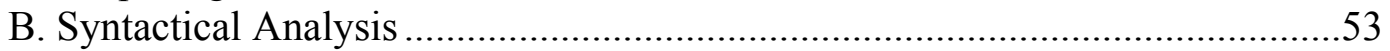

a. Textbooks Associated with Right-wing Groups ................................53

b. Other Textbooks.......................................................................58

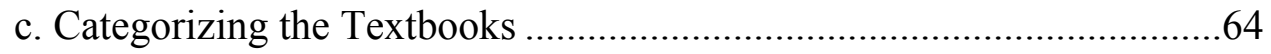

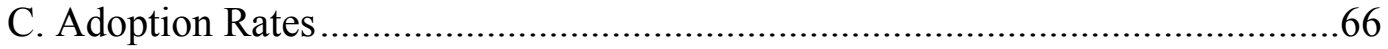

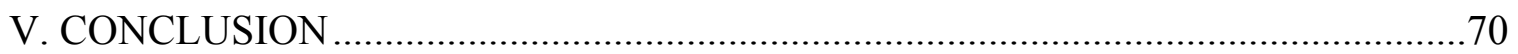

A. The Future of Sino-Japanese Relations....................................................... 70

B. The History Textbook Controversy........................................................ 73

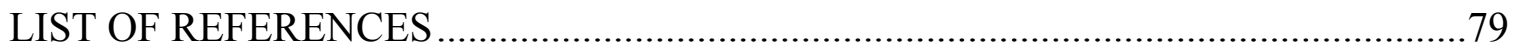

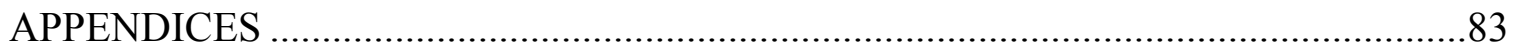




\section{LIST OF FIGURES}

Figure 1. (left) Minnie Vautrin, (center) John Rabe, and (right) Tsen Shui-fang. $\quad 8$

Figure 2. Photographic records of Chinese military personnel being beheaded surfaced at the end of the war.

Figure 3. A member of the Allied force interrogates a Chinese girl from one of the Japanese Army's comfort stations.

Figure 4. Foreign Minister Hirota Koki listens to the verdict.

Figure 5. The process for textbook authorization.

Figure 6. Tsukurukai's first history textbook.

Figure 7. Daiichi Kyōkasho (left) and Japanese history textbooks (right)

Figure 8. "This is [our] new textbook" from Tsukurukai’s website.

Figure 9. A portrayal of Nanjing in a few sentences.

Figure 10. 2012 Textbooks in relation to a Western Historical Consensus. 


\section{INTRODUCTION}

The relations between China and Japan have been strained partly as a consequence of China's grievances concerning Japan's actions during World War II and the allegedly deceitful historiographical accounts found in Japanese history textbooks. These history textbooks, used in primary and secondary schools, which are approved by the Japanese Ministry of Education, Culture, Sports, Science and Technology (MEXT), ${ }^{1}$ have caused a wave of protest within China and South Korea regarding the claimed glossed-over or whitewashed accounts of World War II atrocities. The most contested atrocity affecting the history textbook dispute is the highly controversial Nanjing Massacre (also known as the "Rape of Nanking," a title made famous by the late author Iris Chang), ${ }^{2}$ where a debated number (ranging from an estimated 40,000 to 300,000 ) of Nanjing residents were killed on December 13, 1937 and up to six weeks after the city, located south of Beijing, fell to the Japanese Imperial Army. Other allegedly deceitful accounts of atrocities within history textbooks include the invasion of China, the military skirmish at the Marco Polo Bridge in Beijing on July 7, 1937, and the use of comfort women or non-Japanese Asian women in sex stations for Japanese Imperial troops.

\section{A. Significance of Study}

The reasoning behind researching the Japanese history textbook controversy is founded on the tense relationship between Japan and China, two of the most significant powers in the East Asian region, which continue to dispute over issues that reflect back to

\footnotetext{
${ }^{1}$ In 2001, the Ministry of Education (MOE) and the Ministry for Science and Technology merged to form Ministry of Education, Culture, Sports, Science and Technology (MEXT).

${ }^{2}$ Iris Chang, The Rape of Nanking: The Forgotten Holocaust of World War II (New York: Basic Books, 1997).
} 
the Second World War. According to Ming, in the book Sino-Japanese Relations: Interaction, Logic and Transformation, the issues found in Sino-Japanese relations are all related to history and status:

Historical memory cannot escape politics; government and individuals often select or reimage history to advance their political interest. This book has also shown that how Japanese remember their history is a serious diplomatic issue for China. As such, history triggers intergovernmental exchanges and involves compromise by both sides. ${ }^{3}$

Therefore, my study is significant for several reasons. First, as previously stated, the issue of history is unresolved in Japan and China, causing political disputes, such as the claims to the Senkaku/Daioyu Islands, to continue, which could further harm current relations between these two important nations. Second, as MEXT is the agency that approves history textbooks, it is assumed that the Japanese government has a hand in not only selecting textbooks that whitewash World War II atrocities, but also in editing the textbooks themselves to fulfill a political or historical agenda. Lastly, the Chinese government looks to the Japanese government for a sense of urgency in righting these alleged historical inaccuracies; and, when this does not occur, the Chinese government is quick to publically condemn the Japanese government and attract international attention.

According to Caroline Rose, from Interpreting History in Sino-Japanese Relations and Sino-Japanese Relations: Facing the Past, Looking to the Future?, the Ministry of Education has given authors and editors of history textbooks instructions to "water down" the descriptions of Japan's prewar aggressive behavior, to convey the Meiji Constitution as democratic, and to change various words when regarding war-time

\footnotetext{
${ }^{3}$ Ming Wan, Sino-Japanese Relations: Interaction, Logic and Transformation (Chicago: Stanford University Press, 2006).
} 
events. For example, the words “'invade' (shinryaku 侵略) had been replaced by ‘attack/advance’ (shinkō 侵攻), ‘tyranny’ (kasei 苛政) by ‘oppression’ (assei 圧制), 'oppression' (danatsu 弾圧) by ‘suppression' ([sic] chinatsu 禁圧), and 'rob' (shüdatsu 収奪) by 'transfer' ([sic] jōto 譲与). ${ }^{4}$ She also describes the foundation for China's involvement in the history textbook controversy and their reaction by stating:

Within Chinese lore, the Nanking Massacre has become one of the most powerful symbols of atrocities committed by the Japanese troops in China.... Japan has been slow to acknowledge their role as a victimizer. ${ }^{5}$

Therefore, specific World War II atrocities, such as the Nanjing Massacre, are not only seemingly absent in Japanese history textbooks, but they are also absent in Japan's collective memory, which is a stark contrast to China's collective memory.

\section{B. Research Questions}

The proposed study will examine MEXT's role in the selection of textbooks, used for primary and secondary schools, while also analyzing the politics that could have or have influenced MEXT's decision-making process. My study will also juxtapose the 2001 Atarashii rekishi kyōkasho (New History Textbook 新しい歴史教科書) in contrast with current Japanese history textbooks, as well as the effects of the Japanese history textbooks on Sino-Japanese relations. The questions that the research attempts to answer are:

- How does MEXT regulate the textbook selection process?

${ }^{4}$ Caroline Rose, Interpreting History in Sino-Japanese Relations: A Case Study in Political Decision-Making (London: Routledge, 1998); and Sino-Japanese Relations: Facing the Past, Looking to the Future? (New York: RoutledgeCurzon, 2005).

${ }^{5}$ Rose, Sino-Japanese Relations, 19. 
- How does MEXT regulate the portrayal of World War II atrocities in primary and secondary history school textbooks?

- Do political parties and right-/left-wing organizations influence MEXT's textbook regulation and authorization?

- What is the publisher's role in portraying World War II atrocities in Japanese primary and secondary history school textbooks?

- How do current textbooks portray World War II atrocities (specifically the Marco Polo Bridge Incident and the Nanjing Massacre)?

- What are their adoption rates in the school system?

\section{Hypotheses}

The publishers of the history textbooks portray World War II atrocities in the final version of their history textbooks. However, it has been argued that MEXT and textbook regulation councils (who are sometimes formed with members of political parties, such as the Liberal Democratic Party) emphasize nationalism by adjusting historical inaccuracies, which Japanese courts have held as constitutionally permissible. It has also been argued the MEXT is heavily influenced by right-wing organizations, such as the Japanese Society for a New History Textbook Reform or Atarashii Rekishi Kyōkasho wo Tsukurukai, who create and endorse history textbooks under their own publishing companies. Left-wing groups, such as the Japanese Teacher's Union or Nikkyōsho, challenge MEXT and boycott right-wing history textbooks. The portrayal of World War II atrocities, such as the Marco Polo Bridge Incident and the Nanjing Massacre, found in Japanese history textbooks, varies between textbook publishers. The portrayals within the textbooks that are associated with right-wing organizations are less detailed and have frequent instances of whitewashing, while other textbooks are either more liberal or neutral in their depiction. However, it can be assumed that the more nationalistic and controversial textbooks have an overall low adoption rate within the school system. 


\section{Methodology}

The thesis will utilize historical analysis, based on a general Western historiographical consensus, of the events leading up to the Nanjing Massacre in December of 1937, including the invasion into China, the Marco Polo Bridge Incident that occurred in July of the same year. ${ }^{6}$ My analysis will introduce and compare the historical account with the portrayal found in the Japanese history textbooks in order to confirm or challenge instances of whitewashing. Next, the thesis will research several issues concerning the Japanese history textbook controversy, such as the process and the various theories about MEXT's involvement in the textbook selection, as well as the role of publishers and the involvement of political parties. My thesis will also include quantitative data by comparing statistics regarding the adoption rates of past and current Japanese history textbooks within the primary and secondary academic system. Finally, my thesis will include a syntactical analysis ${ }^{7}$ through my own original translations of key passages that are either included or left out of the 2001 Atarashii rekishi kyōkasho as well as multiple Japanese history textbooks, which, as of 2012, are currently used in the Japanese school curriculum.

\section{E. Note on Formatting}

The romanziation of Chinese names and terms can be quite varied, because of China's current systems of romanization for Mandarin Chinese, pinyin, in comparison with its older system, Wade-Giles. Therefore, an editorial decision was made to use

\footnotetext{
${ }^{6}$ Although Western portrayals are not entirely neutral, they do not show a prejudice against Japan as opposed to Chinese portrayals of history.

${ }^{7}$ A syntactical analysis refers to an analysis of the arrangement and usage of words and phrases within the Japanese history textbooks.
} 
pinyin when referencing places in China, such as "Beijing" instead of "Peking" and "Nanjing" instead of "Nanking." Chinese names will also be given in pinyin with the exception of Chiang Kai-Shek, who was known by Westerners under the Cantonese romanization of his courtesy name. Chiang Kai-Shek's political party, the Kuomintang (KMT), will also be given under it's official name, which continues to use the older system of Wade-Giles. In order to keep the integrity of an author's work, places and names will not be altered in quotes if it is uses the older romanization system of WadeGiles. Japanese and Chinese names will be listed with the family name first, followed by the given name, while Western names will be listed as given name first, followed by the family name.

\section{HISTORICAL BACKGROUND}

\section{A. Atrocities during World War II and the Second Sino-Japanese War}

In 1904, Japan engaged and defeated Russia in the Russo-Japan War. The conflict was the first time an Eastern nation defeated a Western nation, as Japan was recognized as a major actor (and not just an major Eastern actor) in global political affairs. With Russia's defeat, Japan owned and gained access to the South Manchuria Railway, located in what is now northeast China. In 1927, the Communist Party of China (CCP), led by Mao Zedong, and the Nationalist Kuomintang (KMT), led by Chiang Kai-shek (pinyin: Jiang Jieshi), engaged in a civil war to determine which political system would govern China. In the midst of the chaos, Japan coordinated a full invasion of Manchuria in September 19, 1931, through its annexed territory of Korea, after a section of South Manchuria Railway was blown up when explosives were placed on the tracks. Japan gained control over Manchuria, renamed the nation "Manchukuo," and established a pro- 
Japanese government that was led by Puyi, the last Qing emperor. Japan continued its invasion into China, which led the CCP and the KMT to halt the Chinese civil war in order to expel the Japanese Imperial Forces. Although the two countries had fought intermittently, on July 7, 1937, Japanese and Chinese soldiers were engaged in a firefight on the outskirts of Beijing at the Marco Polo Bridge (also known as Luguo Qiao). The firefight led to a quick military skirmish that escalated into a full-scale two-day battle and signaled the start of the Second Sino-Japanese War. As a result of the battle, both Beijing and Tianjin fell to the Japanese Imperial Forces.

In August of 1937, Chiang Kai-shek mobilized a central army and engaged in a three-month battle to defeat and expel the Japanese Imperial Forces in Shanghai. However, China's forces fell, once again, to the Japanese Imperial Army as they made their way to the capital city of Nanjing, while Chiang Kai-shek retreated to the city of Wuhan. Prior to the Japanese Imperial Army's invasion and capture of Nanjing, several Westerners, who were stationed in Nanjing to conduct trade or missions, established the International Committee for the Nanjing Safety Zone and blocked off a portion of the city where they encouraged women, children, and non-military personnel to seek refuge within the Zone. John Rabe, a member of the National Socialist German Workers' (Nazi) Party, led and organized the International Committee for the Nanjing Safety Zone. John Rabe, and several other Westerners, such as Wilhelmina "Minnie" Vautrin and Chinese worker Tsen Shui-fang (see Figure 1), kept record of the "rampage of killing, burning looting and rapping" that caused Nanjing to be "reduced to a "hell on earth." ${ }^{\text {" After the }}$

\footnotetext{
${ }^{8}$ Minnie Vautrin and Tsen Shui-fang, The Undaunted Women of Nanking: The Wartime Diaries of Minnie and Tsen Shui-fang, eds., and trans., Hua-ling Hu and Zhang Lian-hong
} 
war, their records would be vital for the persecution of Japanese officials at the Tokyo Trials after World War II.

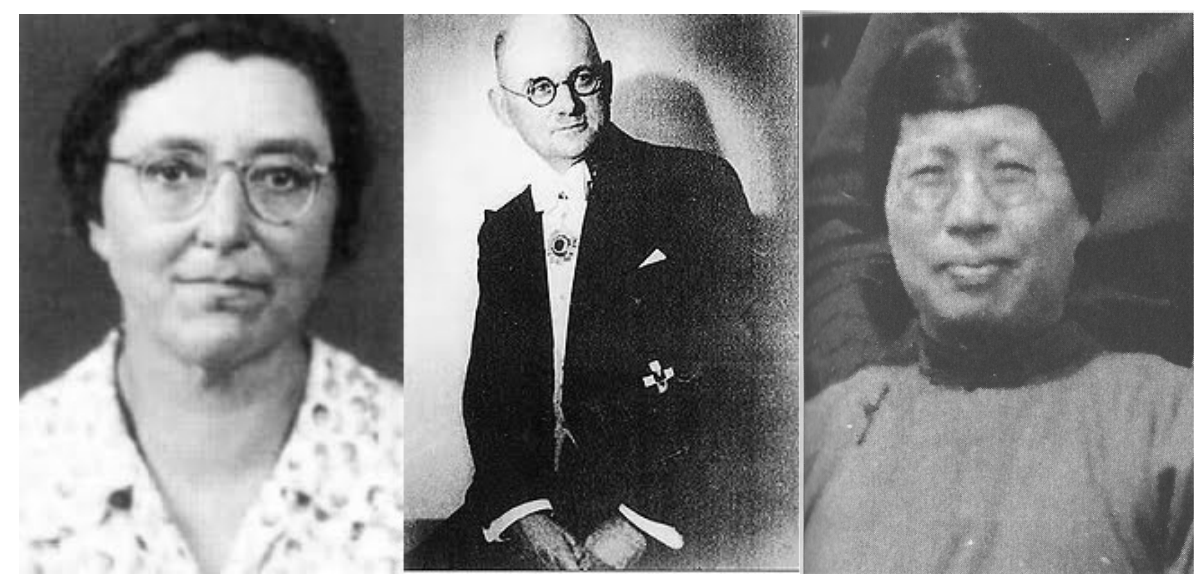

Figure 1. (left) Minnie Vautrin, (center) John Rabe, and (right) Tsen Shui-fang. Source(s): The Undaunted Women of Nanking and The Good German of Nanking: The Diaries of John Rabe.

Prior to the Japanese invasion into Nanjing, John Rabe reached out to Japanese officials to recognize the Nanjing Safety Zone. He received the following response:

Japanese authorities have duly noted the request for safety zone, but regret cannot grant it. In the event of Chinese forced misbehavior towards civilians cannot assume responsibility, but they themselves will endeavor to respect the district as far as consistent with military necessity. ${ }^{9}$

Therefore, the Japanese government did not recognize the Nanjing Safety Zone, and stated that the Japanese Imperial Forces were not responsible for the mistreatment of Chinese civilians. Minnie Vautrin, an American missionary who founded and headed the Ginling Women's College and, at the peak of the Nanjing Massacre, bravely protected over " 10,000 refugees at [an institute] designed originally for $2,750,{ }^{, 10}$ recorded:

(Illinois: Southern Illinois University Press, 2010), 1.

${ }^{9}$ John Rabe, The Good German of Nanking: The Diaries of John Rabe, eds., Erwin Wickert, trans., John E. Woods (London: Little, Brown and Company, 1999), 46.

${ }^{10}$ Vautrin and Tsen, The Undaunted Women of Nanking, 2. 
The Japanese replied that it might or might not recognize the Safety Zone.... We have decided only to received women and children, but not men. Currently, we plan to receive 2,700 people... ${ }^{11}$

As the battle to capture Nanjing commenced, John Rabe placed a German Swastika flag to deter any Japanese Imperial air strikes on the Nanjing Safety Zone. White Red Cross flags were also placed around the border of the Nanjing Safety Zone to deter attacks and welcome those seeking refuge. On December 11, 1937, the Japanese Imperial Forces entered Nanjing and, after three days of intense fighting, the city of Nanjing fell to the Japanese Imperial Forces. The fall of Nanjing to the Japanese Imperial Forces was said to be inevitable because of the city's close quarters with the Yangzi River, which flowed northward and bent towards the eastern portion of the city. Thus, the Japanese Imperial Forces invaded through the south and blocked all routes of possible escape for the Chinese army and the Chinese civilians. The battle for Nanjing also lacked a centralized Chinese military force, as multiple units of the Chinese military had to rely, unsuccessfully, on guerrilla warfare tactics.

After the capture of Nanjing, the Japanese Imperial Army allegedly devised a plot to convince the Chinese populace in Nanjing that mercy and fair treatment would be shown to ex-military personnel if they surrendered peacefully. According to Prince Asaka Yasuhito, cousin to Emperor Hirohito and temporary commander of the forces in Nanjing, over seven thousand Chinese soldiers had gathered around a white cloth attached to a branch to signal their surrender. He stated, "It was funny yet pitiable when I

\footnotetext{
${ }^{11}$ Ibid., 25.
} 
imaged how they gathered whatever white cloth they could find, attached it to a dead twig, and marched forward just to surrender." ${ }^{12}$

On December 12, 1937, as a result of the large number of Chinese prisoners of war that the Japanese Imperial Army could neither house nor feed, the $66^{\text {th }}$ Battalion of the Japanese Imperial Army was ordered to execute all prisoners of war by either dividing the prisoners "intro groups of a dozen"13 or taking soldiers aside to "shoot to kill separately." ${ }^{14}$ The Japanese Imperial Forces gathered those who had peacefully surrendered and escorted them to various areas near the outskirts of Nanjing, where they would either be shot or bayonetted to death. Photos of these incidences have also included the use of katana (traditional Japanese swords) to sever the heads of the Japanese Imperial Force's victims (see Figure 2).

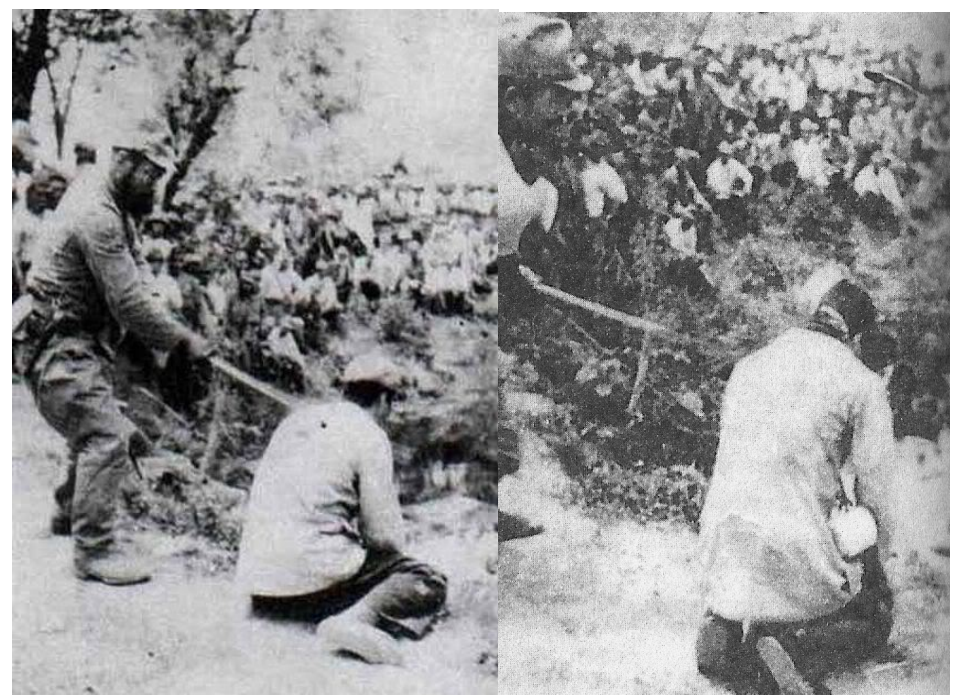

Figure 2. Photographic records of Chinese military personnel being beheaded surfaced at the end of the war. Source: The Good German of Nanking: The Diaries of John Rabe.

\footnotetext{
${ }^{12}$ Iris Chang, The Rape of Nanking, 43.

${ }^{13}$ Ibid., 41.

${ }^{14}$ Ibid.
} 
According to Minnie Vautrin's account, “They took them to our west hill, and there I heard the shots....I wonder how many innocent, hard-working farmers and coolies ${ }^{15}$ have been shot today." ${ }^{16}$ She also wrote, "They have no mercy on Chinese soldiers and do not care much for Americans. ${ }^{, 17}$ In the days following, Chinese prisoners of war, "who had been captured between Hsai and Wuhu...were to be executed on the banks of the Yangtze [Yangzi]." ${ }^{\text {18 }}$ Over fourteen thousand soldiers were taken to the small island of Baguazhou, located in the center of the Yangzi River, where the Japanese Imperial soldiers used their firearms to kill the Chinese prisoners of war. Later, the corpses were either burned or dumped into the river.

Even within the Nanjing Safety Zone, Japanese Imperial Forces would demand entry and take "one thousand disarmed Chinese soldiers, whom the International Committee hoped to save," to be either shot or bayonetted to death. ${ }^{19}$ John Rabe noted that the Japanese Imperial Forces began to rely more on the bayonet because of the loud noise and attention gained by the firearms: “...we foreigners prick up our ears at the sound of machine-gun fire and then inquire about the reason for the shooting. ${ }^{.20}$ John Rabe wrote continuous letters to the Japanese Embassy in Shanghai depicting the

\footnotetext{
${ }^{15} \mathrm{~A}$ "coolie" is a derogatory word for an Asian manual laborer.

${ }^{16}$ Vautrin and Tsen, The Undaunted Women of Nanking, 40-41.

${ }^{17}$ Ibid., 36.

${ }^{18}$ Rabe, The Good German of Nanking, 149.

${ }^{19}$ Ibid., 38.

${ }^{20}$ Rabe, The Good German of Nanking, 99.
} 
atrocities that occurred in Nanjing, and he also urged Japanese officials to intervene in the military's actions. However, an official from the Japanese Embassy threatened that if news of the atrocities were reported in the newspapers from Shanghai, John Rabe would have the Japanese Imperial Army against him. ${ }^{21}$ Consul generals from foreign nations, such as the German consul stationed in Xiaguan, ${ }^{22}$ were prohibited from entering Nanjing as a consequence of the horrendous state of the capital city because the Japanese military officials did not desire a "third country to see their immoral deeds, nor people to see the corpses lying on the roads. ${ }^{, 23}$ John Rabe also wrote full reports of the atrocities to Adolf Hitler, in hopes that the German Führer would send assistance to Nanjing. However, these letters did not receive responses. Prior to the re-admittance of foreign embassies in Nanjing, the "Japanese army attempted to destroy the evidence of the slaughter by wholesale burning the bodies. ${ }^{24}$

According to Susan Brownmiller, who authored Against our Will: Men, Women and Rape, Nanjing was one of the worst occurrence of wartime rapes in history. The scale of rapes and sexual assaults that occurred in Nanjing is unfathomable; however, there were sufficient eyewitness accounts on the acts of rape that were committed by the Japanese Imperial Forces in Nanjing. ${ }^{25}$ According to these witnesses, Japanese Imperial

${ }^{21}$ Rabe, The Good German of Nanking, 186.

${ }^{22}$ Then known as "Hsia Kwan" in the Wade-Giles romanization.

${ }^{23}$ Vautrin and Tsen, The Undaunted Women of Nanking, 59.

${ }^{24}$ Rabe, The Good German of Nanking, 182.

${ }^{25}$ Susan Brownmiller, Against our Will: Men, Women and Rape (New York: Ballantine Books, 1993). 
Forces unceasingly sought women to sexually assault and rape while they looted homes and places of business. The Japanese Imperial Forces actions towards women caused a dilemma for the women of Nanjing to either remain at home in hiding or venture out in the hopes to reach the Nanjing Safety Zone. However, Japanese Imperial soldiers also crossed the threshold of the Nanjing Safety Zone by luring the Western authorities to one area of the Safety Zone, while other soldiers entered the premises in another area and raped women. ${ }^{26}$ According to the diary entries of John Rabe:

...up to 1,000 women and girls are said to have been raped [in one night]; about 100 girls at Ginling Women's College alone. You hear of nothing but rape. If their husbands or brothers intervene, they're shot. What you hear and see, on all sides, is the brutality and bestiality of the Japanese soldiery. ${ }^{27}$

At the Tokyo Trials, James H. McCallum, an American who worked at the Amerian Mission Hospital in Nanjing testified, "Rape. Rape. Rape. We estimate at least 1,000 cases a night and many by day. ${ }^{2} 8$

The young women of Nanjing were not the only targets, as children, older women, and men were also victims of sexual assault and rape. At times, death was the aftermath of these assaults. For example, the American Mission Hospital in Nanjing continuously admitted women who "suffered gravely bodily harm from rape by packs of

\footnotetext{
${ }^{26}$ Vautrin and Tsen, The Undaunted Women of Nanking, 44.

${ }^{27}$ Rabe, The Good German of Nanking, 77.

${ }^{28}$ Shudo Higashinakano, The Nanking Massacre: Fact Versus Fiction A Historian's Quest for the Truth (Tokyo: Sekai Shūpan, 2005), 173.
} 
men with the subsequent infliction of bayonet, and other wounds." 29 Tsen noted, "I could not help but cry. You think it over: If [rape] is not torture then was is torture?"30

Following John Rabe's example, Minnie Vautrin made trips to the Japanese Embassy in Shanghai to report the atrocities and to request an official decree to deter the Japanese Imperial Forces from entering the Nanjing Safety Zone and, specifically, the Ginling Women's College's housing. As a result, Minnie received two night guards and a proclamation to post on the primary gate of the Nanjing Safety Zone. Although the soldiers ignored the proclamation, her efforts were not in vain as the Embassy chauffer expressed his gratitude by stating, "The only thing that had saved the Chinese people from utter destruction was the fact that there were a handful of foreigners in Nanking."31

In late February, foreign embassies were permitted to establish residency in Nanjing once again, and the atrocities were kept to a minimum. Both John Rabe and Minnie Vautrin returned to their homes in Germany and the United States, respectively. Minnie Vautrin experienced a deterioration in mental health and committed suicide in her home by opening the gas in her kitchen stove. Once in Germany, John Rabe tried to communicate with Adolf Hitler concerning the atrocities he witnessed in Nanjing, but Rabe was arrested and later released by the Gestapo. John Rabe later died of a stroke on 1950. Today, his residence in Nanjing serves as the John Rabe and International Committee Safety Zone Memorial Hall.

\footnotetext{
${ }^{29}$ Rabe, The Good German of Nanking, 121.

${ }^{30}$ Vautrin and Tsen, The Undaunted Women of Nanking, 30.

${ }^{31}$ Vautrin and Tsen, The Undaunted Women of Nanking, 49.
} 
During the invasion of China and until the end of World War II, Japan allegedly forced a large number of women and young girls into prostitution, as comfort women, at specific military stations. Prior to this forced participation, comfort women were actually Japanese prostitutes who (sometimes) volunteered their services for the Japanese Imperial Army. However, as the number of prostitutes dwindled and the military continued their expansion into China, Japan turned to the local population and coerced the women into sexual slavery. The coercion came in the form of physical kidnappings or under the pretext of establishing factories or nursing facilities. The term "comfort woman" is derived from the Japanese translation of inafu (慰安婦), as ian (慰安) is “comfort” and fu (婦) is “woman [or women].” The term inafu has as a different connotation than shôfu (娼婦) or “prostitute" (see Figure 3), because ianfu is a title for women who were victimized or forced into sexual labor, while shōfu are women who conduct sexual activity for payment. An estimated 200,000 to 300,000 women across Asia, but predominately in Korea and China, are believe to have been forced into work as sex slaves for the Japanese Imperial Army in brothels. ${ }^{32}$

32 "Sex Slaves put on Trial," BBC News, last modified December 200, accessed January 13, 2013, http://newsbbc.co.uk/2/hi/asia-pacific/1061599.stm. 


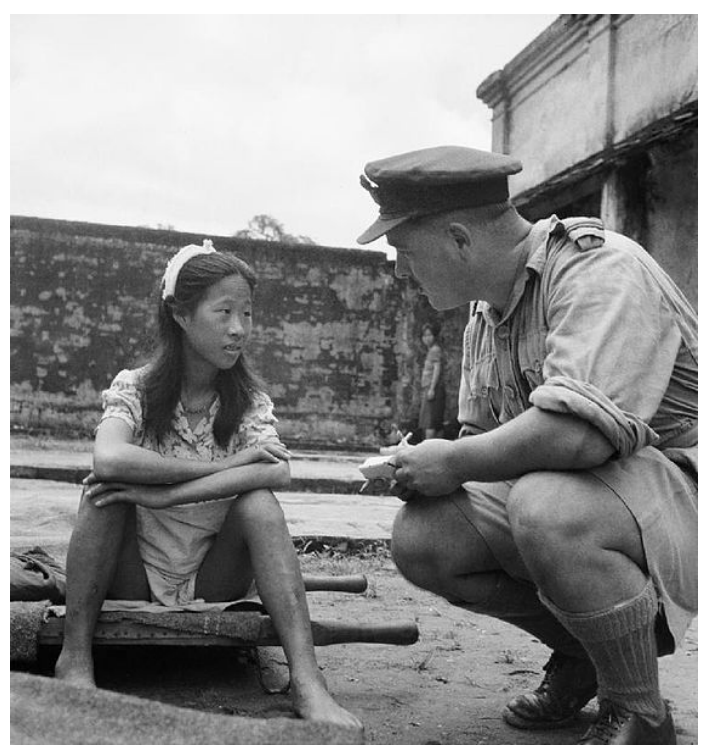

Figure 3. A member of the Allied force interrogates a Chinese girl from one of the Japanese Army's comfort stations.

On December 7, 1941, the Japanese Imperial Navy conducted an air strike on the U.S. naval base at Pearl Harbor located in Hawai'i. Over 180 U.S. aircrafts were destroyed and over 2,000 U.S. naval personnel were killed. On December 11, the United Stated declared war on Japan and joined the Allied Forces in the Second World War. On August 6 and August 9 of 1945, the United States dropped atomic bombs on the cities of Hiroshima and Nagasaki, respectively. On August 15, the Japanese Empire surrendered to the Allied Powers ending both the Second Sino-Japanese War and World War II.

On May 3, 1946, the International Military Tribunal for the Far East (IMTFE), charged Japanese officials who were facing criminal persecution because of their involvement in World War II with three specific classes of wartime crimes: Class A, Class B, and Class C. Class A war criminals were those who were changed with "crimes 
against peace." "Crimes against peace" was defined in Article 5 of the Tokyo Charter

as:

The planning, preparation, initiation or waging of a declared or undeclared war of aggression, or a war in violation of international law, treaties, agreements or assurances, or a common plan or conspiracy for the accomplishment for any of the forgoing. ${ }^{34}$

Class B war criminals were those who were changed with crimes that "violate the laws and customs of war." ${ }^{35}$ Class C war criminals were those who were changed for committing "crimes against humanity." 36 This was defined in Article 5 of the Tokyo Charter as:

...murder, extermination, enslavement, deportation, and other inhumane acts committed before or during the war, or persecutions on political or racial grounds in execution of or in connection with any crimes within the jurisdiction of the Tribunal, whether or not in violation of the domestic law of the country where perpetrated. ${ }^{37}$

The indictment at the IMTFE consisted of fifty-five counts: thirty-six counts of Class A “crimes against peace," sixteen counts of Class B "murder," and three counts of Class C "crimes against humanity." The $45^{\text {th }}$ count was specifically concerning the indictment of Nanjing Massacre:

On $12^{\text {th }}$ December 1937 , and succeeding days, by unlawfully ordering, causing and permitting the armed forces of Japan to attack the City of Nanking in breach of the Treaty Articles mentioned in Count 2 hereof and

\footnotetext{
${ }^{33}$ Timothy Brook, "The Tokyo Judgment and the Rape of Nanking," The Journal of Asian Studies 60, no. 3 (2001): 674.

${ }^{34}$ Ibid.

${ }^{35}$ Ibid.

${ }^{36}$ Ibid.

${ }^{37}$ Ibid., 674-675.
} 
to slaughter the inhabitants contrary to international law, unlawfully killed and murdered many thousands of civilians and disarmed soldiers of the Republic of China, whose names and number are at present unknown. ${ }^{38}$

Counts 46 through 50 charged those accused with the murder of disarmed soldiers and civilians at Guangdong (Count 46), Hankou (Count 47), Changsha (Count 48), Hengyang (Count 49), and Guilin and Liuzhou (Count 50).

Prince Asaka Yasuhito, temporary commander during the events of Nanjing, was not charged for the atrocities as a consequence of the immunity granted to all members of the royal Japanese Imperial family. As a result, two individuals were charged for the atrocities committed in Nanjing: General Matsui Iwane and Foreign Minister Hirota Koki.

General Iwane Matsui was a veteran general who led forces during the RussoJapan War. In the 1930s, he was awarded the Order of the Rising Sun, and went into retirement from active duty. Ten years later, he was asked to lead the Shanghai Expeditionary Force (SEF) with Prince Asaka as his Lieutenant General. General Matsui led the three-month battle to capture Shanghai and gave the command to invade and capture Nanjing as the commander to the Central China Area Army (CCAA). Prior to the invasion on Nanjing, General Mastui released pamphlets into the city, which asked for the unconditional surrender of Nanjing:

The Japanese army shall show no mercy toward those who offer resistance, treating them with extreme severity, but shall harm neither innocent civilians nor Chinese military personnel who manifest no hostility. It is our earnest desire to preserve the East Asian culture. If your troops continue to fight, war in Nanking is inevitable. A culture that has

\footnotetext{
${ }^{38}$ International Military Tribunal for the Far East IMTFE, (1946), 11, quoted in Timothy Brook, "The Tokyo Judgment and the Rape of Nanking," The Journal of Asian Studies 60, no. 3 (2001).
} 
endured for a millennium will be reduced to ashes, and a government that has lasted for a decade will vanish into thin air. ${ }^{39}$

However, prior to the invasion of Nanjing, General Mastui became ill and Prince Asaka became the temporary commander of the Japanese Imperial force in Nanjing.

During his defense throughout the IMTFE, General Matsui claimed that he did "not know of any fact of Chinese women and children being killed within the walls of Nanking, $" 40$ and therefore, could not be responsible for something that did not occur. After rigorous questioning by the prosecutors, General Matsui changed his defense to state that atrocities did occur in the city but, at the time, he was unaware of their occurrence. General Matsui explained in his affidavit, that "a great number of Chinese soldiers and civilians were killed or wounded by bombs, artillery shells and rifle bullets during the Nanking campaign," ${ }^{41}$ which would not be viewed or construed as war crimes. General Matsui also stated that the attack on the city of Nanjing was a defensive strategy to restore order in the region to the south of the Yangzi River and also to deter China's offensive campaign against Japanese Imperial Forces in the Jiangsu and Zhejiang provinces. ${ }^{42}$ His council also argued that this defensive strategy on Nanjing was inconsequential in comparison to the atomic bombings by the United States:

The losses and damages then inflicted on human lives and material things in Nanking are almost insignificant when compared to those that the principal cities of Japan suffered in consequences of the war. More so, would it be if compared to the indescribable horrors to which countless

\footnotetext{
${ }^{39}$ Shudo Higashinakano, The Nanking Massacre, 43.

${ }^{40}$ Brook, "The Tokyo Judgment and the Rape of Nanking," 680.

${ }^{41}$ Ibid.

${ }^{42}$ Ibid., 681.
} 
innocent Japanese women and children and other civilians in Hiroshima and Nagasaki were subjected by the atomic bomb. ${ }^{43}$

Nevertheless, the law governing the tribunals would not allow the defense of one atrocity to cancel out another atrocity. The IMTFE dismissed the first eight of the nine counts against General Matsui stating that he did not conspire or personally commit crimes against humanity in Nanjing, even though he issued the order to capture the city. However, he was found guilty, on count 55, for failing to act to prevent their occurrences and was executed by hanging, at the age of 70, at Sugami Prison located in Ikebukuro. His remains and spirit are enshrined at the controversial Yasukuni Shrine in Tokyo Japan. ${ }^{44}$ Jodai Takuzen, the attorney who defended General Matsui, shared his response to his defendant's fate at the Tokyo Trials:

Every summer the controversy about the Nanking Incident resurfaces, and those who believe it occurred, as well as those who do not, voice their opinions. My heart sinks every time this happens. General Matsui was sentenced to death and executed. But who really believes that there was a massacre in Nanking? I don't think anyone does. ${ }^{45}$

Hirota Koki, the foreign minister at the time of occupied Nanjing until 1938 and former prime minister, was the second individual who was charged for the atrocities that were committed in Nanjing. According to the trial prosecutors, Foreign Minister Hirota

${ }^{43}$ International Military Tribunal for the Far East MTFE, (1948), 98, quoted in Timothy Brook, "The Tokyo Judgment and the Rape of Nanking," The Journal of Asian Studies 60, no. 3 (2001).

${ }^{44}$ Yasukuni Shrine is a Shinto shrine dedicated to those who died in war. The shrine has come controversial due to the enshrinement of war criminal and because of the visits by Japanese prime ministers.

${ }^{45}$ Shudo Higashinakano, The Nanking Massacre, 245. 
was informed of the atrocities that had occurred in Nanjing from the consulate and failed to intervene and, therefore, his "inaction amounted to criminal negligence:"

[Hirota] received reports from the Japanese Embassy in Nanking and from members of the Diplomatic Corps and Press regarding the conduct of the Japanese troops and sent a resumé of the reports to the Japanese Foreign Minister Hirota. These reports, as well as many others giving information of the atrocities committed at Nanking, which were forwarded by members of the Japanese diplomatic officials in China, were forwarded by Hirota to the War Ministry of which Umezu was Vice-Minister. They were discussed at Liaison Conferences, which were normally attended by the Prime Minister, War and Navy Ministers, Foreign Minister Hirota, Finance Minister Laya, and the Chiefs of the Army and Navy General Staffs. ${ }^{46}$

Unlike General Matsui, Foreign Minister Hirota did not provide a written, confirmed by oath, defense and also refused to testify in his own defense. Nevertheless, Foreign Minister Hirota had been accused of "working out the plan for Japanese aggression during his prime ministership, as charged in the other counts on which Hirota was found guilty (see Figure 4)."47

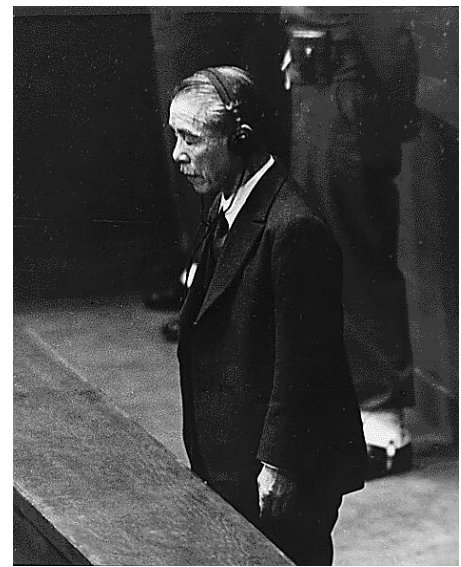

Figure 4. Foreign Minister Hirota Koki listens to the verdict

\footnotetext{
${ }^{46}$ Patrick Clancey, "The IMTFE Judgment," http://www.ibiblio.org/hyperwar/PTO/IMTFE/index.html.

${ }^{47}$ Brook, "The Tokyo Judgment and the Rape of Nanking," 684.
} 
On November 29, his lawyer appealed to the United States Supreme Court that General MacAthur appointed all the judges of the IMTFE, and that it was not an international court in nature. However, the Supreme Court ruled that the IMTFE was indeed international in nature. ${ }^{48}$ Foreign Minister Hirota Koki was convicted, even though his conviction was divided, and was executed by hanging, at the age of 70 , at Sugami Prison located in Ikebukuro. His remains and spirit are also enshrined at the controversial Yasukuni Shrine.

Within the IMTFE ruling of Count 50, which corresponds to the murder of soldiers and civilians in Guilin and Liuzhou, contains what has been read as a reference to comfort women, "During the period of Japanese occupation of Kwelin [pinyin: Guilin], [the Japanese Imperial Forces] committed all kinds of atrocities such as rape and plunder. They recruited women labor on the pretext of establishing factories. They forced the women and thus recruited them into prostitution with Japanese troops." ${ }^{\text {"49 }}$ Although no individual person was convicted for coercing women into sex slavery, it is cited as one of the acts of atrocities with the IMTFE judgment.

The persecution and execution of General Mastui and Foreign Minister Hirota at the International Military Tribunal for the Far East satisfied the interest of the United States for the violent battle and treatment committed by the Japanese Imperial Forces during the Pacific War portion of World War II. Moreover, the trials satisfied the interest

48 "International Military Tribunal for the Far East" International Organization 3, no. 1 (1949): 184-186.

${ }^{49}$ Robert Cryer and Neil Boister, eds., Documents on the Tokyo International Military Tribunal: Charter, Indictment and Judgments (New York: Oxford University Press, 2008), 540. 
of China because "Japanese leaders suffered retribution for the atrocities China endured not just in Nanking but throughout occupied China. ${ }^{, 50}$ However, these convictions were not well received in Japan, as arguments were made that General Matsui and Foreign Minister Hirota were charged, convicted, and seen as criminals by the Allied Powers. Therefore, many Japanese saw themselves as victims, feeling victimized by the Allied Powers for convicting officials who were wrongly held more accountable than those who physically committed the atrocities.

The outcome of the Tokyo Trials, many argue, had a profound influence on the historical interpretation of both World War II and the Second Sino-Japanese War, which led to Japan's collective amnesia about its role in war. According to Ienaga Saburō:

There has been a tendency to reject the Tokyo Trials, in toto ${ }^{51}$ as unfair, and this tendency is linked inseparably with the second tendency: to assert the legitimacy of the war waged by Japan and to suppress or obliterate the aggressive nature of that war and the inhuman criminal activity that took place. $^{52}$

\section{B. Ienaga Saburō and the Beginning of the Textbook Controversy}

After Japan's surrender in 1945 but prior to the education policy ordered by Supreme Commander for Allied Powers (SCAP), the Ministry of Education ${ }^{53}$ issued regulations on Japanese history textbooks based on the revised Japanese Constitution:

\footnotetext{
${ }^{50}$ Brook, "The Tokyo Judgment and the Rape of Nanking," 687.

51 "As a whole"

${ }^{52}$ Caroline Rose, Sino-Japanese Relations, 37.

53 In 2001, the Ministry of Education (MOE) and the Ministry for Science and Technology merged to form Ministry of Education, Culture, Sports, Science and Technology (MEXT).
} 
The following materials ought to be used with care, amended or eliminated: (a) Materials that emphasize national defense and armaments; (b) materials that foster the fighting spirit; (c) material that may be harmful to international goodwill; (d) materials that have become obsolete through being entirely removed from present postwar condition and the everyday life of the students; and (e) other material that are not appropriate in the light of the Imperial Rescript.

In cases where it is necessary to make up for material omitted, select and supplement from the following subjects, keep in mind place and circumstances: materials concerning the maintenance of the kokutai (national entity) and the establishment of high moral education; material suitable for the education of people of a civilized country.... ${ }^{54}$

Therefore, according to these new regulations, teachers and educators were advised to physically cut out the pages or passages in the history textbooks that obtained offensive material until the Ministry of Education could create an appropriate history textbook. In December of 1945, while under the supervision of the SCAP Civil Information and Education Section, the Ministry of Education formed a history textbook committee devised of various historical scholars. Among these scholars, Iegana Saburō, a professor at the Tokyo University of Education, was responsible for the first portion, beginning with ancient time and continuing into the Heian period, the historical depiction of the Kuni no ayumi (The History of the Country 国の歩多) textbook. Iegana's portion required the most adjustment and caused a great deal of disapproval among his peers because of the exclusion of well known legends such as the creation of Japan, as depicted in the Kojiki (Record of Ancient Matters 古事記) and Nihon shoki (The Chronicles of Japan 日本書紀), as well as the existence of Emperor Jimmu, which Ienaga did not

\footnotetext{
${ }^{54}$ Ienaga Saburō, Kindai nihon kyoiku, XXV, 279, quoted in John Caiger, "Ienaga Saburō and the First Postwar Japanese History Textbook," Modern Asian Studies 3, no 1 (1969): 3.
} 
considered accurate or fact. Nevertheless, with these contested omissions, the Ministry of Education published the history textbook.

According to Ienaga, the Ministry of Education encouraged teachers "not to stress the history of struggles for political power or trace the varied fortunes of war and peace, but [instead] to throw light on the actual development of national life from the viewpoint of society, the economy, and culture. ${ }^{.55}$ Therefore, in 1947 the Ministry of Education published Atarashii kenpō no hanashi (Our New Constitution 新しい憲法の話) that stated, "What did Japan gain from the war? Nothing. Was not the only result enormous grief and suffering? War destroys human life and culture. The countries that have started World War II must bear a grave responsibility." ${ }^{56}$ Atarashii kenpō no hanashi also expressed that Japan and Germany needed to accept their responsibility for World War II as well as the vast pain, suffering, and disorder to the world caused by militarist who disregarded the rights of the Japanese people and organized strategies for national security and increase political power.

Eventually, Ienaga expressed "doubt about the future's security and the stability of values that the Ministry of Education had espoused and continued to uphold well after the end of the Occupation.. ${ }^{57} \mathrm{He}$ also reported that the situation drastically changed in the 1950 s as a result of the Ikeda-Robertson talks, which promoted militarism in Japan to increase public support for rearmament. The change in war mentality was an outcome of

\footnotetext{
${ }^{55}$ Caiger, "Ienaga Saburō and the First Postwar Japanese History Textbook," 10.

${ }^{56}$ Ienaga Saburō, The Pacific War, 1931-1945: A critical Perspective on Japan's Role in World War II (New York, Pantheon Books, 1978), 255.

${ }^{57}$ Caiger, "Ienaga Saburō and the First Postwar Japanese History Textbook," 15.
} 
the United States' involvement and need for military assistance in both the Cold War and the Korean War. "Ienaga claimed, "I personally experience that change of policy. In 1963, the ministry refused to approve a high school history textbook I had written."

In 1965, Ienaga Saburō filed a series of lawsuits against the Japanese government and the Ministry of Education, claiming that the screening, suggested revisions and later rejection of his textbook, Shin nihonshi (New Japanese History 新日本史) was unconstitutional following Article 21 of the Japanese Constitution that guarantees the freedom of speech and expression "and declares that no censorship shall be maintained." ${ }^{59}$ Ienaga also claimed that the Ministry of Education had an agenda to whitewash, or deliberately conceal disturbing facts within his account, concerning the Nanjing Massacre and the use of comfort women during World War II in order to protect the children by “hiding the 'darkside' (ankokumen 暗黒面) of Japanese history,” as well as promoting the "love of country education" (aikokushin 愛国心) and “pleasant things" (kireigoto 綺麗事). ${ }^{60}$ For example, in Shin nihonshi, Ienaga wrote: “Immediately after the occupation of Nanking, the Japanese Imperial Army killed numerous Chinese soldiers and citizens. ${ }^{" 61}$ The passage was modified by the Ministry of Education to suggest that

${ }^{58}$ Saburō, The Pacific War: 1931-1945, 255.

${ }^{59}$ Caiger, Ienaga Saburō and the First Postwar Japanese History Textbook quoted from The Japan Times of November 7, 1967 under the heading "State Making Inroads into Education: Nambara."

${ }^{60}$ Randy HuntsBerry, "Suffering History: The Textbook Trial of Ienaga Saburō" Ienagakyokasho saiban, 7 (Tokyo: Sogo Tosho, 1969), 306.

${ }^{61}$ Ienaga Saburō, New Japanese History. Translated by the New League for Support for the School Textbook Screening (1995), quoted in Iris Chang, The Rape of Nanking (New 
the Japanese Imperial Army killed many Chinese soldiers and citizens during the attempt to occupy and capture Nanjing, and not up to six weeks after its capture and surrender, by giving the illusion that the atrocities committed at Nanjing were justifiable as a consequence of war. The passage, concerning the time frame of the Nanjing atrocities, continues to exist in controversial contemporary Japanese middle school history textbooks. Also, the phrase "Japan's aggression" was also contested in Ienaga's textbook by a textbook certifier who requested that Ienaga change the words to "advance" because “in today's societal circumstances, the phrase 'aggressive war' has a very strong connotation of.... criminality; therefore it is a term that in the case of one's own country vis-á-vis another country, is a clear value of judgment. ${ }^{, 62}$ Therefore, Ienaga's manuscript was declared unacceptable because of:

[The explanation] of the Tokugawa era was filled with malice toward the Japanese family system; [the] treatment of peasant uprising seemed to legitimized illegal activity; and [he] devoted many pages to historical facts about the Pacific War and the postwar Era, but these were things the pupils had all experienced, so it would be better to delete them all. ${ }^{63}$

The Ministry of Education also omitted the terms " the war was glorified as a 'holy cause,' 'atrocities by the Japanese troops,' and 'reckless war'" because the terms were objectionable and excessively critical of Japan and its position and actions during World War II. ${ }^{64}$ The Ministry of Education also stated the Japanese students would not

York: Penguin Group, 1997), 206.

${ }^{62}$ Ienaga Saburō, Japan's Past and Japan's Future: One Historian's Odyssey (New York: Rowman and Littlefield Publishers, Inc., 2001), 167.

${ }^{63}$ Ibid., 155.

${ }^{64}$ Ienaga Saburō, The Pacific War, 1931-1945, 256. 
benefit from this information, as it would not give them "a proper understanding of [Japan's] position and actions in the war." ${ }^{65}$ Ienaga Saburō criticized that the interpretation and portrayal of the Second Sino-Japanese War and World War II by the Ministry of Education became the "official version" within Japan because of history textbook approval process, administrative action, scholastic examination, and teacher evaluations.

In 1962, Murakami Hyoe conducted an interview and a survey of teenagers who were born either at the end or after World War II. The results showed, in comparison to a previous survey where the youth had a negative attitude towards the war, that "approval of Japan's actions [in the war had] increased." ${ }^{, 66}$ Some reactions to the war were that "it was unavoidable" or that the "ABCD encirclement [had left Japan with no choice]..."67 Ienaga stated, "The public only wants to forget the unpleasant experience; but collective amnesia will also erase the costly lessons of the war." ${ }^{, 68}$

Ienaga was unsuccessful in his first (1965-1974) and second (1974-1986) lawsuits; however, the final trial of his third lawsuit (1986-1997), at 84 years of age, the judge ruled that the Ministry of Education's textbook authorization system was indeed constitutional, but that its role could not go beyond the rectification of historical facts and typographical mistakes. Conversely, in 1982, the Ministry of Education issued a

\footnotetext{
65 Ibid.

${ }^{66}$ Ibid.

${ }^{67} \mathrm{ABCD}$ is an acronym for the American-British-Chinese-Dutch embargo; Ienaga Saburō, The Pacific War, 1931-1945, 256.

${ }^{68}$ Ibid.
} 
statement to textbook publishers that all history textbooks should use the words “advance/attack (shinkō 侵攻)” rather than “invade (shinryaku 侵略)” when describing Japan's expansion into Manchuria and later into China. The suggested instructions also caused the Ministry of Education to be accused of whitewashing information associated invasion of Manchuria and Korea, which were portrayed, in the textbooks, as "responses

to local resistance." ${ }^{\prime 69}$ Some viewed Ienaga as a "sole sentry in defense of democracy and free education" ${ }^{, 70}$ while others viewed him as a "sinister ally of the extreme left...a communist... and many believe that [his] textbook is laying the foundation for a leftist take over., ${ }^{71}$

\section{THE MINISTRY OF EDUCATION (MEXT)}

\section{A. The Textbook Selection Process}

One of the theoretical arguments concerning MEXT is that emphasizes nationalism by implementing educational reforms, which sets a rigidly high standard in the Japanese educational system, due to political pressure by conservative politicians. According to the Fundamental Law of Education, Article 10, "Education shall be not subjected to improper control." Therefore, political parties, labor unions, private organizations, and religious groups must never interfere with public education. However, the Ministry of Education, which is a part of the government, is regarded as institution that can implement

\footnotetext{
${ }^{69}$ Ibid., 216.

${ }^{70}$ HuntsBerry, "Suffering History," 239.

${ }^{71}$ Ibid.
} 
"improper control.,"72 It is criticized that this "improper control" manifests in textbook approval and textbook censorship.

While textbooks in China (and South Korea) are state-sponsored with very few locally published textbooks, the approval and adoption of textbooks in Japan for public primary and secondary education is framed by a liberal democratic political system, which require that textbooks, made by private companies, pass a strict authorization system and requires that the adoption of textbooks take place as the local level. ${ }^{73}$ Japanese textbooks also have "strict limits to the lengths of the narratives in Japanese middle school and high school textbooks. ${ }^{, 74}$ In Japan, history education begins in the last year of elementary (equivalent to $6^{\text {th }}$ grade in the United States) and is continued throughout high school. In middle school ( $7^{\text {th }}$ grade $-9^{\text {th }}$ grade), social studies is divided into two categories: historical/geographical studies and citizenship studies. In high school $\left(10^{\text {th }}\right.$ grade $-12^{\text {th }}$ grade), world history is compulsory, while Japanese history is an elective. Therefore, elementary and middle school history education focuses on Japanese history, whereas high school education focuses on the history of foreign countries. ${ }^{75}$

Prior to 2005, Japanese textbooks were revised every three years in a continuous rotation. The textbook approved the years before do not have to be completely rewritten for authorization purpose, but both existing textbooks submitted for partial revision or

\footnotetext{
${ }^{72}$ Benjamin Duke, "The Japanese Supreme Court and Governance of Education" Pacific Affairs 10, no. 1 (1980): 77.

${ }^{73}$ Ibid.

${ }^{74}$ Mitani Hiroshi, "Japan's History Textbook System and Its Controversies," in Towards a History Beyond Borders (Cambridge: Harvard University Press, 2012), 241.

75 Ibid., 242.
} 
“revisions authorization (kaitei kentei 改定検定) and newly-complied textbook must be submitted for new authorization. ${ }^{76}$ Currently, Japanese middle school history textbooks are revised once every four years. The announcement of the approval of textbook by MEXT is made in April the year before they are used in the school system, and the adoption of the textbooks by school boards is completed in August. MEXT reviews the page proofs of the unpublished history textbooks submitted by each publisher the year prior to the announcement of the adoption and also requires more than six months to review the textbooks (see Figure 5).

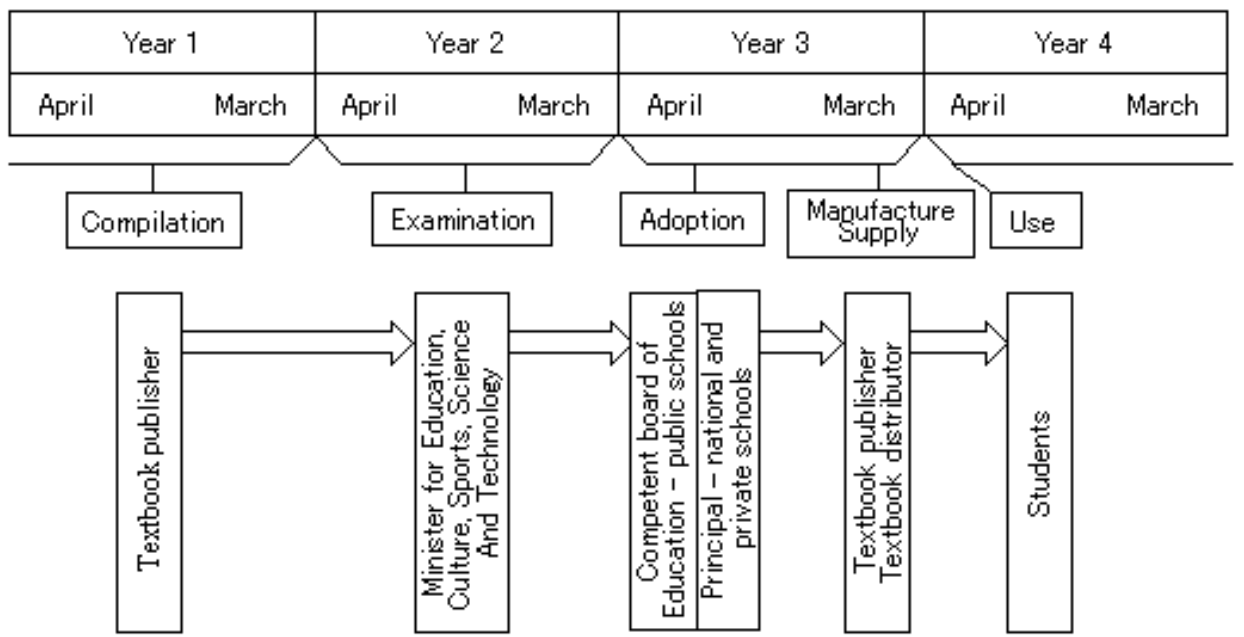

Figure 5. The process for textbook authorization.

Source: Ministry of Foreign Affairs of Japan Website (http://www.mofa.go.jp/policy/education/textbooks/overview-1.html).

These procedures and standards are established within the Regulation for Authorization of Text for Education Use and the School Course Guidelines. The Textbook Authorization and Research Council, comprised of over one hundred educators, from elementary to university level, are appointed by MEXT to review and examine the content of the textbooks. It should be noted that MEXT rarely overturns the approval or

${ }^{76}$ Rose, Interpreting History in Sino-Japanese Relations, 68. 
disapproval of a textbook by the Textbook Authorization and Research Council. However, the Textbook Authorization and Research Council will withhold its decision to reject a textbook by delivering, to the publisher and authors, a written authorization stating that the textbook received a conditional pass, a list of revisions, and will also “give the publisher an oral explanation."”7 These recommendations (kenkai 見解) for rewriting, editing or omitting certain portions of the textbook demanded as voluntary revisions since the publisher "wants their book to be certified."

Currently, Japan is divided into 583 textbook adoption districts that are comprised of prefectural and municipal boards of education. These prefectural and municipal boards of education, which can represent up to three cities or counties, are made up of principals, teachers, and members of the board of education as well as others with experience in education. Each public school does not choose its own textbook from the authorized list except for private schools, which make up about 1 percent of all of schools in Japan and 6 percent of all students. ${ }^{79}$ Therefore, each prefectural and municipal boards of education establishes a textbook advisory committee, who offer guidance to the public schools by producing "a list of materials to be considered for each subject area based on research done by teams of several teachers." ${ }^{80}$ During the guidance process from a textbook advisory committee, the opinions of students' parents are also taken into consideration

\footnotetext{
${ }^{77}$ Ibid, 245.

${ }^{78}$ Terri Seddon, "A Case Study of the Japanese History Textbook Dispute: 1982," British Journal of Sociology of Education 8, no. 2 (1987): 215.

${ }^{79}$ Hiroshi, “Japan's History Textbook System and Its Controversies,” 246.

${ }^{80}$ Ibid., 247.
} 
and the authorization process reflects the decisions of local residents and educators. The final decision for the textbooks is decided at an adoption conference. After the adoption conference, the textbook are provided to students from public schools, free of charge, while students who attend private schools must purchase the specific textbook from a textbook retailer that services their district or ward.

The continued animosity towards Japan by its neighboring nations as a result of the approval of textbooks that "whitewash" historical accounts have caused the global community to become aware of the seemingly lack of transparency and the ambiguous interpretation of Japanese educational policies. Also, the seemingly authoritarian control of the MEXT in regards to the national symbols such as the national flag and anthem have caused civil outcry. However, this does not solely define the Japanese education system, as there are several factors that refute this theoretical perspective.

\section{B. MEXT, Tsukurukai, and the 2001 Atarashii rekishi kyōkasho}

It has also been argued that MEXT could be influenced by nationalistic or rightwing organizations to spread nationalism within the Japanese educational system. This was something that was found in the majority of the research, as all information regarding the Japanese education system based on a pessimistic bias towards MEXT concerning the history textbook controversy.

During the Cold War era, the differences between China and Japan's interpretation of World War II and the Second Sino-Japanese War surfaced as a bilateral political issue that progressed into the twenty-first century. In the 1990s, there was a focus on "the memory boom" through various media such as articles, testimonies, documentaries, museums dedications, and exhibitions that began to question the previous 
practices of collective memory, as people from both nations actively sought to uncover the truth. According to Vera Zolberg:

The problem of knowing what "really" happened becomes more complex the more we know, the more viewpoints expressed, the thicker the description. Indeed, a nation's "official history" conventionally highlights its glories. But this idea is increasingly being subjected to "readers" who wish to know what really happened. ${ }^{81}$

In order for a history textbook to be used in the Japanese national school curriculum, the textbook must be either approved by MEXT or be published under its copyright. ${ }^{82}$ According to MEXT, the governmental control of the textbooks gives students equal opportunities to education while improving education standards throughout Japan. ${ }^{83}$ As a consequence of these high education standards, schools are permitted to select from only five to seven Ministry approved history textbooks for one academic year. Therefore, the approval of alleged whitewashed textbooks has called to question the authority of MEXT and the Japanese government. It is important to note that MEXT not only approves history textbooks for school use but also rectifies historical facts and typographical errors within the textbook, which, as of $1997,{ }^{84}$ the Japanese courts have held as constitutionally permissible.

${ }^{81}$ Rose, Sino-Japanese Relations, 51.

${ }^{82}$ The 2001 Atarashii rekishi kyōkasho and the 2012 textbooks are not published under the MEXT's copyright. However, the dates of MEXT examination and authorization found with the bibliographical information.

83 "Improving the Textbook Authorization System." Ministry of Education, Culture, Sports, Science and Technology, November 30, 2011, http://www.mext.go.jp/b_menu/hakusho/html/hpae199401/hpae199401_2_092.html.

${ }^{84}$ The courts deemed, at the conclusion of Ienaga Saburō's trial in 1997, that the textbook authorization system does not interfere with constitutional rights. 
However, those who claim it is in violation of human rights, as it is a form of censorship from the Japanese government, have vigorously challenged this authorization system over many years. According to Teruhisa Horio, author of Educational Through and Ideology in Modern Japan:

Even though the Ministry of Education has tried to represent this system as a neutral attempt to eliminate politically biased opinions or as a scientifically objective effort to correct mistaken information, it in fact constitutes nothing less than an attempt to keep out of our schools all ideas which do not fit with the State's view of the kinds of knowledge which are both appropriate and desirable to administer to Japanese youth. ${ }^{85}$

As stated by textbook authors and editors interviewed by the Asahi Shimbun, since the 1980s, all the textbooks have been subject to the similar instructions by the Ministry of Education:

1. To water down as much as possible descriptions of Japan's prewar aggressive behavior

2. To write about the democratic nature of the Meiji Constitution

3. To use more honorific expression when referring to pre-Nara Emperors

4. To explain that the Self Defense Forces (SDF) were established according to the SDF Law

5. To stress Japan's right to possession of the Northern Territories

6. To stress citizens' duties rather than rights

7. To stress the contribution of big business [to Japan's development] ${ }^{86}$

Asahi Shimbun also reported that the following places within one textbook in particular, Nihonshi (Japanese History 日本史), were revised by the Ministry of Education:

\footnotetext{
${ }^{85}$ Teruhisa Horio, Educational Thought and Ideology in Modern Japan: State Authority and Intellectual Freedom (Tokyo: University of Tokyo Press, 1988).

${ }^{86}$ Rose, Interpreting History in Sino-Japanese Relations, 82.
} 
1. A title, Japan's Invasion of China (Nihon no chūgoku shinryaku 日本 の中国侵略), was changed to The Manchurian and Shanghai Incidents (Manshu Jihen/Shanghai Jihen 満州事変／上海事変).

2. The phrase 'The fifteen year war that started with the invasion of Manchuria' became simply 'The war....'

3. A caption under a map "Japan's invasion of China' (Nihon no chügoku shinryaku 日本の中国侵略) became 'Japan's encroachment into/invasion of China' (Nihon no chügoku shinnyū 日本の中国侵入).

4. 'Mao Zedong....fought against Japan invasion' (Mō Takutō wa...Nihon no shinryaku to tatakau 毛沢は...日本の中国侵略と戦う) was changed to 'Mao Zedong... fought against Japan's attack/advance' (M̄̄ Takutō wa...Nihon no shinkō to tatakau 毛沢は... 日本の進行と戦 う). ${ }^{87}$

In the example above, the Ministry of Education was criticized by left-wing media, such as the Asahi Shimbun, for creating a political agenda to eliminate any criticism towards the Japanese Imperial Army in China. Consequently, since the 1980s, it has become routine for Asahi Shimbun to report the results of the history textbook authorization, as Chinese media also relied on the press coverage to fuel its campaign.

Prior to 1991, the issue of the historiographical portrayal of comfort women was seemingly unimportant until a former comfort woman from South Korea, Kim Hak Sun, broke her 50 years of silence to discuss her experience as a woman forced into military sexual slavery by Japan. Once her account became public, several more women not only in South Korea but other Asian nations, such as China and the Philippines, disclosed their experiences as comfort women. Her account encouraged Japanese human rights activists, specifically female activists, to organize support groups for women who were victimized by Japan. Kim Hak Sun and several other South Korean women filed the first of many

${ }^{87}$ Ibid., 89. 
lawsuits against the Japanese government in December of 1991. During this time, the Japanese government denied their involvement in the coercion of women into sexual slavery and refused to apologize, provide reparations, or carry out an investigation of the accusations.

In the following year, Japanese historian, Yoshimi Yoshiaki, discovered and disclosed official documents in the National Institute of Defense Studies that proved that the military had played a role in the organization and control of comfort stations in Asia. In his research, he not only found that the Japanese government and military had fully planned and established the operation of comfort women stations but also that various Japanese officials, governor generals, and Foreign Ministry officials were involved in the activities as well. Moreover, he discovered that the Japanese Imperial Forces set up many comfort stations they occupied areas in China. ${ }^{88}$ Yoshimi also stated the military was in violations of basic human right, as there were various instances of sexual, racial, economic and ethnic discrimination aside from the obvious violation to women's rights. Furthermore, the use of comfort stations was to deter and prevent the military from raping local women but, with the establishment of the comfort stations, the instances of rape did not diminish. ${ }^{89}$ As a result of Yoshimi Yoshiaki's research, Prime Minister Kiichi Miyazawa publicly admitted and apologized for the Japanese military involvement in the comfort women system during World War II and the Second Sino-Japanese War.

\footnotetext{
${ }^{88}$ Hirofumi Hayashi, "Disputes in Japan over the Japanese Military "Comfort Women" System and Its Perception in History," Annals of the American Academy of Political and Social Science 617 (2008): 123-132.

${ }^{89}$ Ibid.
} 
Prime Minister Kiichi Miyazawa's apology was the first time in history that a Japanese official apologized for the atrocity.

In 1993, as a consequence of the admission of the use of comfort women during World War II by Prime Minister Kiichi Miyazawa and later Chief Cabinet Secretary Kano Yohei as well as its inclusion in Japanese middle school history textbooks, a committee was formed from the heads of the Liberal Democratic Party (LDP), such as Hashimoto Ryūtarō, Mori Yoshirō, and Nakayama Tarō, called the Committee on History and Screening (Rekishi kentō iinkai 歴史検討委員会), which sought to investigate

historical information. Their objective was to give a nationalistic summary of Japan's role during World War II. For example, they produced a summary of Japan's involvement in the war that expressed that Japan was acting in self-defense during the World War II as well as the Second Sino-Japanese War. Moreover, that the alleged atrocities were purely fabrications to demean Japan. ${ }^{90}$ Therefore, these fabrications, such as Nanjing Massacre, comfort women, and Unit 731, needed to be stamped out and denied from history textbooks; an imagery that is similar to "a contemporary fumie or brass tablets [with a depiction of Jesus Christ or the Virgin Mary] that suspected Christians in the seventeenth-century had to stamp on to prove they did not belong to that faith." ${ }^{91}$ Nevertheless, this has caused more controversy because of the removal of all references to the estimated or debated number of Chinese killed during the Nanjing Massacre because of insufficient evidence.

\footnotetext{
${ }^{90}$ Ming Wan, Sino-Japanese Relations.

${ }^{91}$ Roger B. Jeans, "Victims or Victimizers? Museums, Textbooks, and the War Debate in Contemporary Japan," The Journal of Military History 69, no. 1 (2005): 188.
} 
These findings of the Committee on History and Screening were published as a book, Daitōa sensō no sōkatsu (Summary of the Greater East Asian War 大東亜戦争の

総括), on August 15,1995 , the $50^{\text {th }}$ year anniversary of Japan's surrender. Within their

summary, the Committee on History and Screening stated that a textbook debate was necessary as a result of the exaggerated emphasis on "damage" and "invasion" in recent textbooks and that a national movement was also needed to disseminate the correct historical view that was put forward within the book. The organization also expressed their dissatisfaction with Prime Minister Murayama Tomiichi's apology for war atrocities in $1995 .{ }^{92}$

Along with the formation of the Committee of History and Screening was the launch of the Atarashii Rekishi Kyōkasho wo Tsukurukai (Japanese Society for History Textbook Reform 新しい歴史教科書をつくる会; furthermore known as "Tsukurukai"), by University of Tokyo Professor Fujioka Nobukatsu, whose goal was to give a "healthy," nationalistic account to schoolchildren while building their sense of dignity in Japanese history, which "plays an important role in the construction of contemporary Japanese national identity."${ }^{, 93}$

However, these views did not go unchallenged by academics as Japanese textbook author and professor Obinata Sumio stated:

${ }^{92}$ Rose, Sino-Japanese Relations, 58.

${ }^{93}$ Alexander Bukh, "Japan's History Textbook Debate: National Identity in Narratives of Victimhood and Victimization," Asian Survey 47, no. 5 (2001): 687. 
Professor Fujioka often talks about a "history to be proud of." Unfortunately, the facts include some things that we can't be proud of. Is it wrong to teach about them? I don't think so.... Faithfulness to the facts naturally means inclusion of both the good and the bad. History education isn't ethics, and it is not a matter of saying, "Read this and be uplifted." The factual record includes some bitter parts, but they're historical facts, so pupils need to deepen their understanding of them. ${ }^{94}$

According to scholars, the backdrop for these right-wing developments was Japan's first recession since the post-war era and, later, the funds given by the Japanese government to aid the Gulf War. The economic crisis caused a spread of fear and uncertainty as unemployment and crimes rates rose. Tsukurukai stated that aside from children losing their sense of dignity in Japanese history, Japan was depicted "as a criminal on whose shoulders fate has placed the burden of atoning for their sins for generations to come." $" 95$

Although Tsukurukai played an active role in the campaign in the textbook battle, the LDP played a supporting role. In 1996, Ōkuno Seisuke and over 100 members of the LDP formed the Diet Member's Alliance for a Brighter Japan (Akarui nihon kokkai giin renmei 明るい日本国会次委員連盟) to discuss the textbook process, as the textbook issues was raised on Diet sessions theat were held on December 11 and 18. Opposition parties and the Japan's Teachers' Union, advocating a return to authoritarianism in education, criticized LDP members. However they were not deterred in their mission, as the LDP and right-wing organizations were active in launching campaigns to encourage local assemblies and councils to sign petitions that called for the deletion of passages and

94 Jeans, "Victims or Victimizers? Museums, Textbooks, and the War Debate in Contemporary Japan," 187-188.

${ }^{95}$ Hiroshi, “Japan’s History Textbook System and Its Controversies,” 255. 
strengthen the textbook authorization system. In September of 1996, the campaign targeted 339 city and town councils and 31 prefectures assemblies. Citizens groups, women's rights activists, and unions groups opposed this campaign.

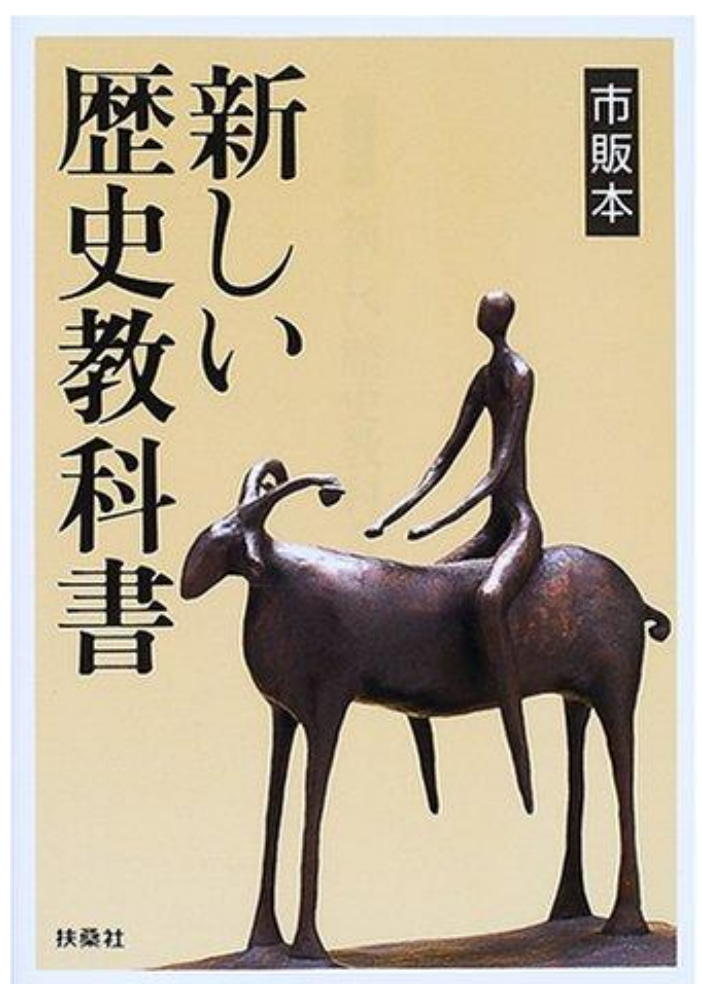

Figure 6. Tsukurukai's first history textbook.

As an organization, Tsukurukai created their own history textbook, Atarashii rekishi kyōkasho (New History Textbook 新しい歴史教科書), and lobbied influential LDP members, utilized citizens movements and meet with local assemblies, who were concerned with education, to exert pressure on the Ministry of Education to approve their textbook (see Figure 6). In 2000, the manuscripts of several history textbooks, which were sent for approval by the Ministry of Education and assumed to be secret, were uncovered to the public. The uncovering of the manuscripts led to the dismissal of a member of the Textbook Authorization and Research Council as well as a number of 
"critical reports on the content of the Tsukurukai textbook." ${ }^{96}$ As a result, before its official approval and adoption, Atarashii rekishi kyōkasho gained a lot of attention. During the authorization process, the Committee for Truth and Freedom in Textbooks issued a highly signed petition that asked the Ministry of Education to reject Atarashii rekishi kyōkasho's manuscript because they claim that the textbook will "pave the way for the revival of chauvinistic history education of pre-war and war-time Japan..97

The United Nations Educational, Scientific and Cultural Organization (UNESCO) also invited representative from China, South Korea and Japan to discuss the textbook controversy, but the latter declined their involvement. However, the textbook also opened a forum for discussion and support for organizations such as the Violence again Women in War: Japan, and the Center for Research and Documentation on Japan's War Responsibility. Since there was no hope of reaching an agreement on an official level, these organizations, as well as academic institutions and individual researchers were involved in the Asian Solidarity Conference on Textbook Issues in Japan. The Asian Solidarity Conference on Textbook Issues also attracted participants from China, Indonesia, South Korea, Malaysia, the Philippines and Taiwan. Therefore, the failure of dialogue, on an official level, strengthened the voice of NGOs to establish a link between traditional forms of a civil society in order to discuss the textbook issue and devise a plan of action aimed to stop the use of Atarashii rekishi kyōkasho in schools.

\footnotetext{
${ }^{96}$ Ibid., 254.

${ }^{97}$ Carolina Rose, Sino-Japanese Relations, 63.
} 
Nevertheless, the conferences were criticized for only analyzing Japan's involvement in the textbook controversy as though it was only culprit in adjusting their history textbooks. For example, Falk Pingle argues:

The instances of Korean collaboration or the civil war that took place in China, causing serious casualties and weakening Chinese resistance against the Japanese forces were not mentioned. The participants did not see the need to question their own history and communication was asymmetrical. One only partner that was expected to make concessions and to change the textbook representation of the others' role, where as the other two partners seems to be sacrosanct. ${ }^{98}$

The Ministry of Education required revisions on over 137 points of Atarashii rekishi kyōkasho. The majority of these issues were classified as "simple factual errors," but there were instances where the issues could be considered "politically motivated" according to the School Course Guidelines (Gakushū shidō yōryō 学習指導要領) and the

Regulations for Textbook Authorization (Kyōkasho kentei kijun 教科書検定基準). ${ }^{99}$

Tsukurukai implemented all of the requested changes and the Ministry of Education authorized Atarashii rekishi kyōkasho to be used in the school system. Tsukurukai released a statement in celebration of their victory:

We affirm that we have now reached a new historical stage in which we can break free from the vicious circle of outside pressure from South Korea and China followed by ingratiating responses, a pattern that has repeated itself since 1982 and has hindered the development of sound relations between our country and those two countries. ${ }^{100}$

\footnotetext{
${ }^{98}$ Falk Pingel, "Can Truth Be Negotiated? History Textbook Revision as a Means to Reconciliation," Annals of the American Academy of Political and Social Science 617 (2008): 196.

${ }^{99}$ Hiroshi, “Japan’s History Textbook System and Its Controversies,” 257.

${ }^{100}$ Ibid., 257-258.
} 
Atarashii rekishi kyōkasho, by the publishing company Fusōsha and the nationalist group Tsukurukai, became the most recent controversial history textbook because of a seemingly ambiguous account of the atrocities committed by the Japanese Imperial Army. For example, the passage translated from page 295 of the 2001 edition of Atarashii rekishi kyōkasho states, "Furthermore, doubts have been raised concerning the circumstances of this incident (the Nanjing Incident), and there are various contested opinions so that even today this debate continues." ${ }^{101}$ Although it is true that there are various opinions concerning the events of the Nanjing Massacre, such as the estimated number of casualties, the words, "doubt has been raised concerning the circumstances of this incident," gives legitimacy to those who believe that the Nanjing Massacre was either greatly exaggerated or altogether false. Others view this attitude as being similar to the denial of the Holocaust. Within the seven history books that were sent for approval to the Ministry of Education, only one contained a satisfyingly detailed account of war atrocities by the Japanese army. According to critics, the term “invade (shinryaku 侵略者 or shin” nyū 侵入)” was replaced by “advance (shinkō 進行 or susume 進め), ” the mentioning of United 731 and the use of comfort women where omitted and the "Nanjing Massacre (Nankin daigyakusatu 南京大虐殺)” was toned down by renaming the event as the “Nanjing Incident (Nankin jiken 南京事件).” Nevertheless, with the leaked information, Tsukurukai, in an attempt to appeal to the general public and make their textbook official, made the final version of their approved textbook on sale for the public.

101 Atarashii rekishi kyōkasho (Tokyo: Fusōsha, 2001), 295. 
The 2001 edition of Atarashii rekishi kyōkasho gained a lot of media attention in China and invoked a response from the South Korean Ambassador to Japan, Choi Sangyong, who was asked to return to South Korea to investigate the issue and file a formal complaint against the Japanese government. Upon Choi Sang-yong's return, the South Korean President, Kim Daejung, also issued a halt of all Japanese cultural imports and listed all the content within the textbook that required revision. Chinese Ambassador to Japan, Chen Jian, also held a press conference to condemn the textbook for its historical inaccuracies and urged for a diplomatic resolution by demanding that MEXT recall the textbook and issue an immediate revision. The press conference led to official meetings between foreign ministers and ambassadors.

Japanese officials expressed that the views of Fusōsha and the Atarashii rekishi kyōkasho textbook were not the opinions of the Japanese government or people and stated, "It could not satisfy China's demand for making further revisions of the history textbook because there is no obvious deviation from historical facts in the book." 102 Because of this statement and the lack of initiative by the Japanese government, important visits by Chinese officials to Japan and Japanese officials to China were canceled. Additionally, South Korean hackers tampered with and crashed the official websites of the Ministry of Education, Fusōsha, and the Liberal Democratic Party. ${ }^{103}$ Fujioka Nobukatsu defended Tsukurukai and the Atarashii rekishi kyōkasho textbook by

\footnotetext{
${ }^{102}$ Rose, Sino-Japanese Relations, 25.

103 Jeans, "Victims or Victimizers? Museums, Textbooks, and the War Debate in Contemporary Japan," 190.
} 
stating, "All nations have a right to interpret their history in their own way and pass down that interpretation. I think that is a part of sovereignty." 104

The Atarashii rekishi kyokkasho textbook not only omits the mentioning of comfort women and the scientific experiments conducted at United 721 but also whitewashes other events such as the formation of the Greater East Asia Co-Prosperity Sphere, the military conflict at the Marco Polo Bridge, and the Nanjing Massacre. The conflict at the Marco Polo Bridge and Nanjing Massacre are compressed to only one page in the entire textbook. Atarashii rekishi kyōkasho was also criticized for having a passive and excusatory tone for all controversial events. For example, the reasoning for stationing 4,000 troops around the vicinity of Beijing was the result of the treaty Japan had with China after the Boxer Rebellion. It also claimed that the Marco Polo Bridge Incident was an act of self-defense, which was triggered by someone who fired shots at the Japanese Imperial Army. It then goes on the state that the entire outbreak of the Second Sino-Japan War was the result of the shooting and killing of two Japanese officials at a foreign interest meeting in Shanghai, and not the Japanese invasion of Mainland China and the state of belligerence in Shanghai.

The information regarding the Nanjing Massacre was limited to only two sentences (see Appendix A):

Thinking that Chang Kai-shek would surrender at the fall of the Kuomintang government's capital city, the Japanese army occupied Nanjing in December. [Note] At this time, many Chinese soldiers and civilians were killed or wounded by Japanese troops - the Nanjing Incident. $^{105}$

${ }^{104}$ Ibid.

${ }^{105}$ Atarashii rekishi kyōkasho, (Fusōsha, 2001), 270. 
The issue, as previously stated, is the indication that the Japanese only killed many Chinese soldiers and civilians during the siege for Nanjing, which is not the case since the Chinese were said to be victimized also after Nanjing's surrender. Many Chinese and South Korean scholars were concerned that textbooks, like Atarashii rekishi kyōkasho, promote Japanese nationalism, which could eventually lead to the remilitarization of Japan. They have reasoned that if schoolchildren do not learn the accurate accounts of history, then history will once again repeat itself. Christopher Bernard questions the campaign of right-wing organization by stating:

I would further claim that the highly vocal campaign within Japan that calls into question the brutality of Japanese aggression, together with the teaching of a type of history that shies away from pinning down the responsibility for the atrocity, creates a climate of opinion within modern Japanese society that allows the historical fact of the Rape of Nanking to be either held up to questioning, or at least its magnitude to be doubted. ${ }^{106}$

In 2005, Fusōsha submitted a newly revised version of Atarashii rekishi kyōkasho, which was also approved by MEXT. The textbook caused another round of public demonstrations in China (and South Korea) against the MEXT and the Japanese government for not revising the previously stated errors within its 2001 version and only correcting typographical errors. However, these historical facts, like the number of citizen and soldiers killed at the Nanjing Massacre have been debated and therefore excluded from textbooks based on the guidelines that prohibits the disclosure of a definitive conclusion to matters that are unresolved. The continuation of the alleged whitewashing of events have partially caused tense relations with South Korea and China in 2005.

\footnotetext{
${ }^{106}$ Christopher Barnard, "Isolating Knowledge of the Unpleasant: the Rape of Nanking in Japanese high-school textbooks," British Journal of Sociology of Education 22, no. 4 (2001): 527.
} 
However, the tension also resulted from the contention between Japan and its neighboring countries due to Japan's request of a permanent seat in the United Nations Security Council, territorial disputes, the Japanese prime minister's visits to the controversial Yasukuni Shrine, as well as the use of the Self Defense Force aid the United States and the United Kingdom during against the War on Terror. These relations have not only sprouted anti-Japanese sentiments within neighboring counties, but also hinder important diplomatic meetings that promote peace and international cooperation.

To counter the lobbying of Tsukurukai, progressive citizens groups networked with liberal organizations, such as Japan's Teachers' Union, and Children and Textbooks Japan Network 21, ${ }^{107}$ to persuade school boards to reject the selection of Atarashii rekishi kyōkasho. ${ }^{108}$ A survey of the 583 school districts, conducted by Children and Textbook Japan Network 21, found that the 2001 Atarashii rekishi kyōkasho had a .039 percent adoption rate (around 11 schools throughout Japan) that later increased, minimally, to .046 percent (see Table 1). Administered prefectural schools in Ehime and also a few private schools in Tokyo adopted the textbook, and thus, no public school in cities, towns, or villages adopted the textbook. The adoption rate of the 2005 Atarashii rekishi kyōkasho increased to 0.5 percent, and middle schools in Tokyo's Suginami ward became first public middle school ward to adopt Atarashii rekishi kyōkasho.

${ }^{107}$ Children and Textbooks Japan Network 21 is a NGO, which was formed in 1998, that protest historical revisionism and fights the removal of material of Japan's war record from textbooks.

${ }^{108}$ Claudia Schneider, "The Japanese History Textbook Controversy in East Asian Perspective" Annals of the American Academy of Political and Social Science 617 (2008): 111. 


\begin{tabular}{l|ll}
\hline PUBLISHER & \# OF BOOKS & $\%$ OF TOTAL \\
\hline TOKYO SHOSEKI & 676,434 & 51.241 \\
OSAKA SHOSEKI & 185,397 & 14.044 \\
KYOIKU SHUPPAN & 171,533 & 12.994 \\
TEIKOKU SHOIN & 144,215 & 10.925 \\
NIHON SHOSEKI & 77,598 & 5.878 \\
SHIMIZU SHOIN & 33,346 & 2.526 \\
NIHON BUNKYO & 30,968 & 2.346 \\
FuSŌSHA & $\mathbf{6 0 1}$ & $\mathbf{0 . 0 4 6}$ \\
\hline TOTAL & $1,320,092$ & 100.000 \\
\hline
\end{tabular}

Table 1. Adoption rates for textbook in 2001 including Atarashii rekishi kyōkasho Source: Table adapted from Mitani Hiroshi "Japan's History Textbook System and Its Controversies," 265.

These adoptions percentages fell short of Tsukurukai's goal, but their direct cause for the textbook's unsuccessfulness was the undesired media coverage as well as Fusōsha's lack of experience in producing a textbook that could compete with those of well-known and accredited publishers. Although there were education officials who supported the ideals of Tsukurukai and its Atarashii rekishi kyōkasho, these officials had "little reason to risk being the target of so much mass-media coverage by choosing their textbook, ${ }^{, 109}$ as there were other authorized textbooks and less controversial textbooks

${ }^{109}$ Hiroshi, "Japan's History Textbook System and Its Controversies,” 259. 
that "deleted references to the comfort women and eliminated Marxist-derived

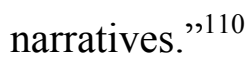

As a result of pressure from right-wing organization, the LDP and the Ministry of Education, the portrayal of Chinese or Korean women who were forced sexual labor was removed and the term "comfort women" could no longer be found within any of the middle school history textbooks that approved were by the Ministry of Education in 2005. These organizations, political parties, and government agencies also pressured authors and publishers to drastically cut the mentioning of Japanese aggression and atrocities within their history textbooks. ${ }^{111}$

As a response to ease international tension, the Ministry of Foreign Affairs made various sections of eight 2005 MEXT approved textbooks available to the public. These sections included the original Japanese text as well as translations into English, Chinese, and Korean. The available translations also included Japan's other textbooks, which represented 99 percent of Japan's middle school history textbooks. Prior to this act, foreigners and neighboring counties had suspicions about the depiction of history within the Japanese middle school textbooks but had no direct access to the textbooks' content.

By providing the original text and translation to all of the eight approved textbooks, the Ministry of Foreign Affairs took the focus away from the Tsukurukai's Atarashii rekishi kyōkasho and gave foreign and neighboring nations the opportunity to judge the content and middle school history textbooks for themselves. The translation of

${ }^{110}$ Ibid.

${ }^{111}$ Hiyashi Hirofumi, "Disputes in Japan over the Japanese Military 'Comfort Women' System and Its Perception in History," 123-132. 
the textbooks had great meaning in the long run for the Ministry of Foreign Affairs. ${ }^{112}$ In addition, many educators came together in order to developed supplementary teaching materials that were translated into Chinese and Korean, which were later sold in each country simultaneously. Through the process, despite critical opinions, these nations became familiar with the teaching and education practices within each nation. Although Atarashii rekishi kyōkasho remains within the selection of textbooks authorized by MEXT, “it will most likely remain a marginal presence on the textbook market."113 Therefore, it can be argued that it is right-wing organizations' and not neccessarily the Ministry of Education's agenda to promote nationalism within the Japanese education system.

\section{2012 JAPANESE MIDDLE SCHOOL HISTORY TEXTBOOKS}

\section{A. Acquiring the Textbooks}

The latest Japanese history textbook controversy occurred in 2006, and even though this issue is fairly recent, I found that acquiring the newest MEXT-approved Japanese middle school history textbooks was vital to gain a first-hand knowledge of the controversy. Although seemingly trifling, acquiring the textbooks determined if I could pursue my research topic. Moreover, acquiring these textbooks was as much of a challenge as was their translation since the Ministry of Foreign Affairs no longer provides scans or translations to the textbooks since the controversy in 2006. The 2001 Atarashii rekishi kyōkasho was acquired online in 2011. However, in order to purchase this specific textbook the correct name of the textbook, the publishing company, the year

${ }^{112}$ Hiroshi, “Japan's History Textbook System and Its Controversies,” 262.

113 Ibid. 
of publication and front cover image was required, as there have been many Atarashii rekishi kyōkasho textbooks published since the initial 2001 edition. Nevertheless, the major issue was purchasing a textbook that is not usually sold in the United States, but this feat was achievable to through online retail sources.

I obtained six middle school history textbooks and one high svhool history textbook from Daiichi Kyōkasho (First Textbook [Store] 第一教科書, see Figure 7). ${ }^{114}$

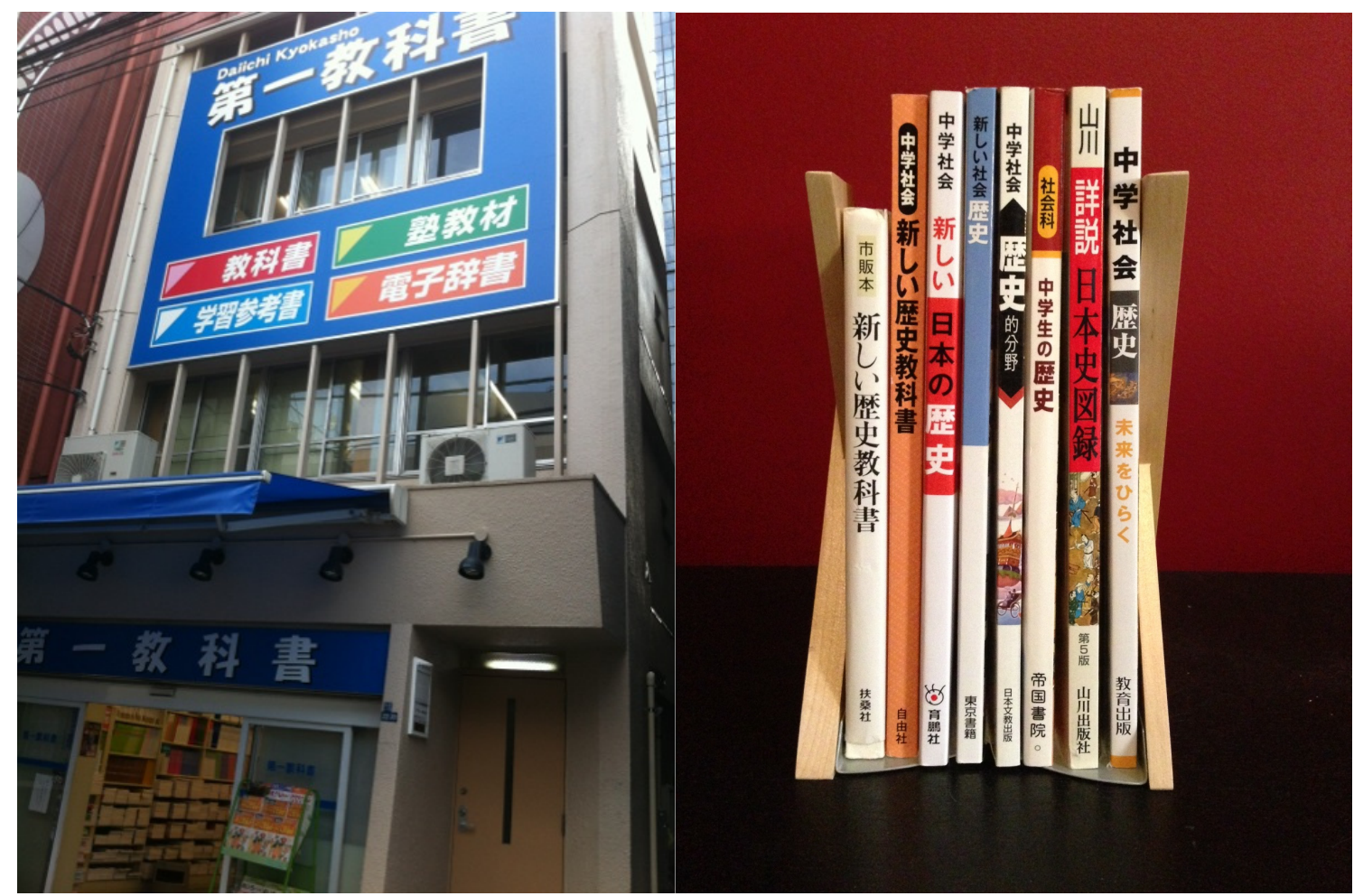

Figure 7. Daiichi Kyōkasho (left) and Japanese history textbooks (right).

${ }^{114}$ Although my researched is based on the middle school history textbooks, I purchased a high school textbook to also view its content and superficially compare it to the middle school textbooks. 


\section{B. Syntactical Analysis}

\section{a. Textbooks Associated with Right-wing Organizations}

If we look at the history textbooks, it has been argued that there is a dominant narrative and a consistent disparity between the events that isolates knowledge from Japan and its students. According to Christopher Barnard:

In modern Japan, two of the main arguments used by those who deny the occurrence, or at least the scale, of the Rape of Nanking, are: first, it could never have happened, since Japanese people only found out about it after the war; and second it is a fabrication by the Allies, which was part of their administrations of "victors' justice' to the Japanese. ${ }^{115}$

Currently, two textbooks in particular, Chugaku shakai: Atarashii rekishi kyōkasho (Middle School Social: New History Textbook 中学社会: 新しい歴史教科書) by Jiyūsha (Freedom, Inc. 自由社) and Atarashii Nihon no rekishi (New Japanese History 新しい日本の歴史) by Ikuhōsha (Peng Education Company 育鵬社) are supported by Tsukurukai or former members of Tsukurukai (see Figure 8) and bear a striking resemblance to the controversial 2001 Atarashii rekishi kyōkasho.

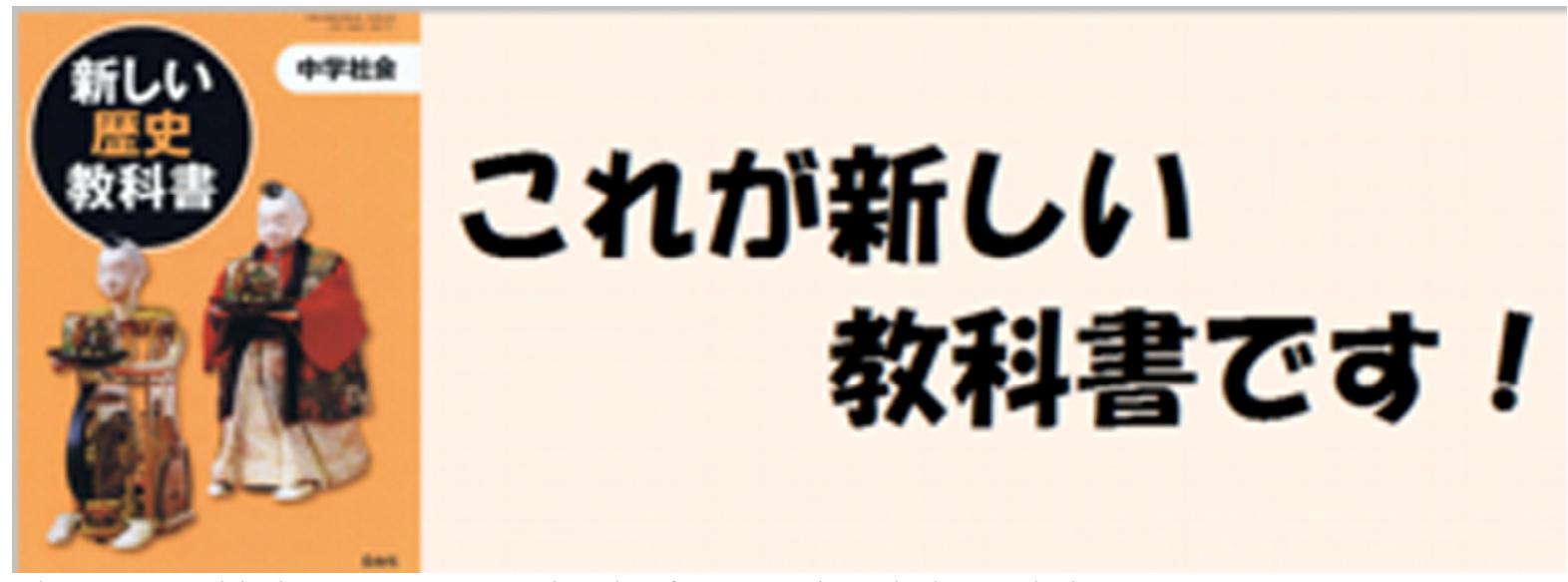

Figure 8. "This is [our] new textbook" from Tsukurukai's website.

${ }^{115}$ Christopher Barnard, "Isolating Knowledge of the Unpleasant," 527. 
Three of the six Japanese middle school history textbooks commence with the invasion of China by mentioning Manchuria. The portion within the history textbooks that portrays the invasion of China and the Marco Polo Bridge Incident, which started the Second Sino-Japanese War, usually leads to text referring to the Nanjing Massacre (see Appendix B):

In order to secure Manchuria and maintain resources, the Japanese army formed a pro-Japanese administration adjacent to northern China that led to the heightening of tensions with China. Japan stationed 5,000 troops around the vicinity of Beijing due to the treaty Japan and other Great Powers had with China after the Boxer Rebellion. ${ }^{116}$

A careful reading of the text will show the justification to Japan's military presence in Manchuria as well as Beijing with the words "in order to secure Manchuria and maintain resources." Atarashii rekishi kyōkasho and Atarashii Nihon no rekishi omit the incident at the Southern Manchurian Railway that led to Japan's invasion into Manchuria and specifically states that, as a consequence of the treaty after the Boxer Rebellion in 1901, Japan had a legal right to station troops within China, which at the time was not unified with Manchuria. Moreover, the statement referring to the Boxer Rebellion found in the Atarashii Nihon no rekishi textbook also entirely omits the invasion into Manchuria by stating, "After the Boxer Rebellion Treaty, Japan stationed 5,000 troops around the outskirts of Beijing." ${ }^{, 117}$ The passage may cause an impression that Japan had already established a legal military presence in China, specifically Beijing, through the Boxer Rebellion Treaty, prior to the Second Sino-Japanese War. However, since China was not a unified nation at the time, as it was engaged in a civil war prior to

${ }^{116}$ Chūgaku shakai: Atarashii rekishi kyōkasho (Tokyo: Jiyūsha, 2012), 225.

${ }^{117}$ Atarashii Nihon no rekishi (Tokyo: Ikuhosha, 2012), 209. 
World War II and the Second Sino-Japanese War, the Boxer Rebellion Treaty might have no longer been recognized.

One issue, which requires a detailed reading of the text, is the lack of perpetrators in the events that led up to the Nanjing Massacre. For example, when referring to the Marco Polo Bridge Incident, Chugaku shakai: Atarashii rekishi kyōkasho by Jiyūsha and Atarashii Nihon no rekishi by Ikuhōsha refers to it as "an incident [that] occurred when someone fired shots at the Japanese army while they were engaged in maneuvers at the Marco Polo Bridge near the outskirts of Beijing." The question of concern is: Who is this "someone?" These two textbooks mention that the Japanese Imperial Army was near Beijing; and since Japan had "advance" into China, one can assume, since this "someone" was shooting at the Japanese Imperial Army in Beijing, that this "someone" was a Chinese military personnel. Nevertheless, the wording causes Japan to be viewed as a victim, who was defending against a military assault, instead of a victimizer who invaded a nation. The victim/victimizer portrayal can also been seen in the same two textbooks, which reference the killing of two Japanese officials in Shanghai: “...in Shanghai, an incident occurred where two Japanese officials were shot to death by Chinese troops.... Thus, the [Second] Sino-Japanese began and expanded."118

On December 13, 1937, after three days of intense battle, the capital city of Nanjing fell to the Japanese Imperial Forces. The weeks following the capture where met with countless atrocities towards prisoners of wars and civilians not limited to women and children. Although the Nanjing Massacre is mentioned within all six Japanese middle school history textbooks, there are various instances of glossed over information or tricky

${ }^{118}$ Chūgaku shakai: Atarashii rekishi kyōkasho, 225. 
wordplay that seems to downplay the atrocities committed by the Japanese Imperial Army (see Appendix B):

Thinking that Chang Kai-shek would surrender with the fall of the Kuomintang government's capital city, the Japanese army occupied Nanjing in December. However, Chang Kai-shek moved the capital to inner Chongqing and the hostilities continued. ${ }^{119}$

[Note] During capture of Nanjing, the Japanese army killed or wounded many Chinese soldiers and civilians (the Nanjing Incident). ${ }^{120}$

The example above, found in Chügaku shakai: Atarashii rekishi kyōkasho, gives the illusion that the atrocities committed at Nanjing were justifiable as a consequence of war because the Japanese Imperial Army killed many Chinese soldiers and citizens during the attempt capture Nanjing and not up to six weeks after its surrender. The justification of the attack on Nanjing is stated as a military strategy to force Chiang Kai-shek to surrender. Within the six Japanese middle school history textbooks, the information regarding the Nanjing Massacre is limited to approximately three to four ambiguous and vague sentences with further explanation reserved in footnotes (located on the sides of the page) that also vary in length. The Chūgaku shakai: Atarashii rekishi kyōkasho textbook, out of the six, contained the smallest amount of information regarding the Nanjing Massacre (see Figure 9).

119 Ibid.

${ }^{120}$ Ibid. 


\section{日本軍は国民政府の首都南京を落とせば蒋介石は降伏す}

\section{ると考え，12月，南京を占領した。しかし，蒋介石は奥}

地の重慶に首都を移し，抗戦を続けた。

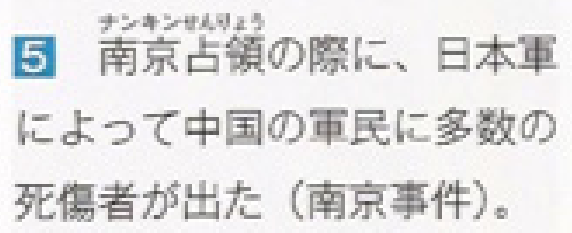

Figure 9. A portrayal of Nanjing in a few sentences. ${ }^{121}$

Source: Chūgaku shakai: Atarashii rekishi kyōkasho

Although the 2012 Chügaku shakai: Atarashii rekishi kyōkasho and Atarashii Nihon no rekishi textbook are the most closely related to the 2001 and 2005 Atarashii rekishi kyōkasho, the publishing company Fusōsha disassociated with Tsukurukai in 2006 but continued to work with former members, such as Yagi Hidetsugu, to publish another textbook edited by Kaizennokai. Fujioka Nobukatsu, who remained with Tsukurukai, found another publisher, Jiyūsha, and declared that they would also be preparing a new textbook. Although both textbooks were approved by MEXT in 2009, a lawsuit erupted due to the similarities in the textbooks' content. The adoption of the textbooks did not spark an international controversy due to the improvements "from the 2001 and 2005

${ }^{121}$ Thinking that Chang Kai-shek would surrender with the fall of the Kuomintang government's capital city, the Japanese army occupied Nanjing in December. However, Chang Kai-shek moved the capital to inner Chongqing and the hostilities continued. [Note] During capture of Nanjing, the Japanese army killed or wounded many Chinese soldiers and civilians (the Nanjing Incident); Ibid. 
versions [by] making its wording more harmonious with the thinking of other countries." 122

The statement, "Furthermore, doubts have been raised concerning the circumstances of this incident (the Nanjing Incident), and there are various contested opinions so that even today this debate continues"123 no longer appears in the textbook or in any of the six textbooks acquired. The deletion of this statement is a stark contract from the earlier version of this textbook, and it could be also be a factor as to why the history textbook controversy is no longer in the forefront of Sino-Japanese relations. In 2011, Fusōsha sold the rights to the earlier history textbooks (the 2001 and 2005 Atarashii rekishi kyōkasho) to its subsidiary company, Ikushōsha, as Fusōsha no longer publishes textbooks under its name.

\section{b. Other Textbooks}

Although Chugaku shakai: Atarashii rekishi kyōkasho by Jiyūsha and Atarashii Nihon no rekishi by Ikuhōsha are supported by nationalist or right-wing groups, the other textbooks do, to some degree, use wording that can be criticized as whitewashing. The main criticism towards Japanese middle school history textbooks is the wording regarding wartime events. For example, the term “invade (shinryaku 侵略者 or shin”nyū侵入)” has been replaced by “advance (shinkō 進行 or susume 進め)” to give a defensive response for the action held accountable by the Japanese Imperial Army. The term "invade" implies that the offending country is the aggressor, while "advance"

122 Gilbert Rozman, U.S. Leadership, History, and Bilaterial Relations in Northeast Asia (UK: Cambridge University Press, 2010), 111.

${ }^{123}$ Atarashii rekishi kyōkasho (Tokyo: Fusōsha, 2001), 295. 
implies more a neutral military term or a military maneuver. The mentioning of "advance" can be seen in the following example in Shakaika chügakusei no rekishi: Nihon no ayumi to sekai no ugoki (Social Studies Middle School: History of Japan and the Movement of the World 社会科中学生の歴史：日本の歩みと世界の動き) by Teikokushoin (Empire Publishing 帝国書院) (see Appendix C):

Japan was internationally isolated and became close with Germany who similarly withdrew from the League of Nations. This furthered the antagonism with the United States and Great Britain. Additionally, Japan advance its army into not only "Manchukuo," but also northern China. ${ }^{124}$

Not only does the passage above state that Japan "advance" into Manchuria and Northern China, but the tone of the text can been seen as self-justifying as it claims that Japan was "internationally isolated." The passage also mentions Japan's antagonism towards the United States, who was not involved in World War II until 1941; four years after Japan invasion of China and two years after Great Britain's declaration of war on Germany. Nevertheless, two of the six Japanese middle school history textbooks, Chügaku shakai rekishi (Middle School Social History 中学社会歴史) by Nihonbun Kyōshuppan (Japan Education Publishing 日本文教出版) and Chūgaku shakai rekishi: Mirai no hiraku (Middle School Social History: Opening the Future 中学社会歴史 : 未来のひらく) by Kyōikushuppan (Education Publishing 教育出版) do not mention the invasion of Manchuria, but refer to the political state of China prior to and during Japan's invasion (see Appendix D):

In China, at the time, the Kuomintang government was in the middle of a civil war against the Communist Party, led by Mao Zedong. The

${ }^{124}$ Shakaika chūgakusai no rekishi: Nihon no ayumi to sekai no ugoki (Tokyo: Teikokushoin, 2012), 209. 
Communist Party, which moved its base to Yan'an, sought cooperation with the Kuomintang government in order to resist the Japanese, and in 1936, the civil war came to a standstill. ${ }^{125}$

The passage gives an accurate portrayal that of the situation in China during the 1930's, and also points out that the CCP and the KMT had to temporarily halt the civil war in order to resist the invasion of the Japanese Imperial Forces into China.

There is also a dispute on how criticism of the Nanjing Massacre is portrayed in the Japanese middle school history textbook. According to Christopher Barnard, in Isolating Knowledge of the Unpleasant: The Rape of Nanking, "when criticism is removed from people who carry out heinous acts to the content of the event, or even the event itself, then it is not frank criticism." ${ }^{126} \mathrm{He}$ also gives an example referring the Holocaust by stating, "killing people in death camps was evil." However, this statement alone is not enough to criticize those who carried out the terrible acts and should be restated, as "the German [soldiers] who killed people in death camps were evil." Nevertheless, he noted in his translations of several 1995 Japanese textbooks that there is a lack of criticism towards those who carried out the terrible acts during the Nanjing Massacre. Although the textbooks refers to the Japanese Imperial Army as having captured Nanjing, the translations of the 2012 Japanese middle school history textbooks also portrays the presence of the army at the organization level instead of at an individual or human level.

The Japanese Imperial Army, as a whole, is not directly criticized, instead the actions that constitute the event ("acts of brutality") are criticized in the following

${ }^{125}$ Chügaku shakai rekishi: Mirai no hiraku, (Tokyo: Kyōikushuppan 2012), 213.

${ }^{126}$ Barnard, "Isolating Knowledge of the Unpleasant: The Rape of Nanking," 524. 
example: "In Nanjing, many Chinese including soldiers, women, and children were killed causing foreign countries to accuse the Japanese Imperial Army for 'acts of brutality' (The Nanjing Massacre)." ${ }^{, 27}$ The passage, found in the Shakaika chügakusei no rekishi: Nihon no ayumi to sekai no ugoki textbook, seemingly shows no introspection from Japan by stating that only foreign countries accused Japan, and therefore suggests that Japan has no guilt or atonement for these actions. As a counterargument, this can also suggest that the event was such a concern that it caused the international community to criticize Japan. The words "acts of brutality" are used in quotes in the original Japanese text. However, the use of the quotation marks remains unclear, as there is no note to suggest that the phrase was quoted from a specific person.

The event is also indirectly given a name, such as the Nanjing Incident or Nanjing Massacre (see Appendix E):

[Note] The incident, the Nanjing Massacre, gained international criticism and was unknown to the Japanese populace until they were informed after the war at the Tokyo Trials. Various investigations and studies were conducted in regards to the number of victims, but the decision has not yet been settled. ${ }^{128}$

Therefore, in the previous example, only the event or "incident" is criticized, internationally, as there are no persons, organizations, groups or actions that receive direct criticism. Although it is common to give an important historical event a specific name, it has been criticized that calling the Nanjing Massacre the "Nanjing Incident" downplays the scale and significance of the atrocity. Another point, from the previous passage, is that the events of the atrocity was seemingly kept from the Japanese populace,

${ }^{127}$ Shakaika chūgakusai no rekishi: Nihon no ayumi to sekai no ugoki, 209.

${ }^{128}$ Atarashii shakai rekishi (Tokyo: Tokyo Shoseki, 2012), 194. 
and suggests that the knowledge of the Nanjing Massacre was kept isolated form Japan. The previous example also suggests that the "whole world could know about something, but not Japan — as if Japan was in some way not part of the world."129 Similarly, by whom was "this incident" not made know to the Japanese people? A closer reading of the text suggest that this is in reference to the military and governmental authorities that hid the atrocities that occurred in Nanjing from the Japanese people. However, the text and textbooks change the wording to avoid any direct suggestions or accusation that the information and knowledge of the Nanjing Massacre might have been covered up by military and government authorities, while "making conscience efforts to isolate the knowledge of Nanking."130

Although Japanese middle school history textbooks have been criticized for its glossed over or "whitewashed" portrayal of the Nanjing Massacre, within my research I have found that the most glossed over textbooks are associated with right-wing organizations, such as the textbooks supported by Tsukurukai, while other textbooks give a more detailed account of the World War II atrocities. For example, within the Chügaku shakai rekishi textbook (see Appendix F):

Nanjing was the capital city [of China] in December where many prisoners of war, women, and children were detained and many citizens were killed (Nanjing Incident). ${ }^{131}$

[Note] At the time, the Japanese citizens were not informed of this incident. Investigative documents were presented at the Tokyo Trials. Then, it was revealed, in a later study that examples of various killings

${ }^{129}$ Barnard, "Isolating Knowledge of the Unpleasant," 256.

${ }^{130}$ Ibid.

${ }^{131}$ Chūgaku shakai Rekishi: Nihonbun Kyōshuppan, 226. 
were written down in the diaries of military units and officers. However, the extent of the killing is unknown and further research is necessary. ${ }^{132}$

Within this passage, there are several examples of consistency with Western portrayals concerning the Nanjing Massacre. First, the text does not mention the words "during that time" when discussing the Nanjing Massacre, which suggest that the atrocity happened up to six weeks after its surrender and not during the capture. Second, the text mentions prisoners of war who were killed in Nanjing. The mentioning of prisoners of war solidifies not only the previous statement regarding the timeframe of the Nanjing Massacre, but also shows that the Chinese soldiers had surrendered or were captured and defenseless but were killed nonetheless. The passage also goes into more detail concerning the victims, as it mentions women and children.

Finally, the text mentions the diaries of military personnel, which seemingly erases any notion that the Nanjing Massacre could have been fabricated because of the statement that entries were found in the diaries of Japanese military personnel, as opposed to the diaries of Westerners who have been criticized for exaggerating the events of Nanjing as a result of a predisposition to be prejudiced toward the Japanese. Although an approximate number of those killed in Nanjing is not mentioned, the text highlights that more research on the Nanjing Massacre is necessary. According to the Standards for Authorization of School Textbooks for Use in Compulsory Education, as of 2005 it states:

1. No present definitive conclusion on unsettled current issues.

2. In dealing with events in the modern and contemporary history of relations with neighboring countries of Asia, giving appropriate

${ }^{132}$ Ibid. 
consideration to viewing them from the standpoint of international understanding and international cooperation.

3. In giving dates for important events in Japanese history, giving the year according to both the Western calendar and the Japanese imperial era system.

Thus, the approximation or estimation of those killed in the Nanjing Massacre cannot be present in any of the Japanese middle school history textbook due to the lack a definitive or official number.

Even though all of the textbooks mention the Nanjing Massacre, the mentioning of comfort women is not present in any of the 2012 Japanese middle school history textbooks. Within the indexes of each textbook, I search for the words ianfu or jügun ianfu (military service comfort women 従軍慰安婦), but the search yielded no results. While the removal of comfort women within history textbook has been due to the pressure of right-wing organizations, political parties and allegedly the Ministry of Education, the subject of comfort women might too mature or complex for children with ages ranging from 12 to 16 . Moreover, this can be said for the subject of rape when discussing the Nanjing Massacre, as the specific word "rape" is not mentioned within the history textbooks.

\section{c. Categorizing the Textbooks}

Through the analysis of the content of the history textbooks, the textbooks were categorized and separated between textbooks that are associated with right-wing organizations, such as Tsukurukai, and those that are not associated with right-wing organizations. The portrayals of Japan's involvement in the Second Sino-Japanese War can vary with the textbooks that are not associated with right-wing organizations, from consistent with Western portrayals to somewhat neutral or divergent with Western 
portrayals. Figure 10 shows a scale of the six 2012 textbooks and their relationship with the portrayals that are consistent with Western historical consensus.

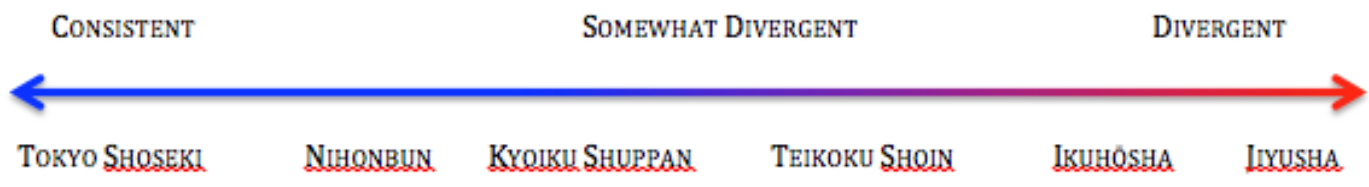

Figure 10: 2012 Textbooks in relation to a Western historical consensus.

The textbooks that are the most consistent are published by Tokyo Shoseki and Nihonbun and give a detailed account of Japan's involvement in the war. The textbooks mention the state of China prior to the invasion, use the term "invade" instead of "advance," mention women, children and prisoners of war, and do not include the words "during this time" when referring to the Nanjing Massacre.

The textbooks issued from Kyōikushuppan and Teikokushoin give a portrayal of Japan's involvement in the war that diverges somewhat from Western accounts. The textbooks are less detailed than the textbooks by Tokyo Shoseki and Nihonbun and show some instances of ambiguity (such as using the term "advance" or stating that Japan was internationally isolated), but they mention the political state of China before the Second Sino-Japanese War, as well as women, children and prisoners of war, and do not use the words "during this time" when referring to the Nanjing Massacre.

Jiyusha and Ikuhōsha are the textbooks that provide the least amount of information. Neither textbooks mention the state of China prior to the war, and both rationalize the invasion into China via Manchuria. Both textbooks state that the military skirmish at the Marco Polo Bridge was due to "someone" who fired shots, refer to the Nanjing Massacre as solely the "Nanjing Incident," and use the words "during this time" 
when referring to the timeframe of those who were killed in the Nanjing Massacre. Through the analysis of the content of the history textbooks, there can be a comparison between six 2012 textbooks (and their consistency with Western historical consensus) to the adoption rates within the Japanese educational system.

\section{Adoption Rates}

Although there are no official reports of the adoption rates for the new 2012 Japanese middle school history textbooks, the textbook store, Daiichi kyōkasho (First Textbook 第一教科書), where I purchased the textbooks, posted a list of each schools' (within its district) textbook adoption for elementary, middle, and high school. Daiichi kyōkasho, located in near the Okubo station in Shinjuku, Tokyo, is responsible for providing textbooks to the fourth district schools in Shinjuku, Shibuya, Nakano, and Suginami. These textbooks are also available for individual purchase, as this is how I acquired the textbooks without any affiliation to a school. Through a PDF provided in Daiichi kyōkasho's website (see Appendix G), I was able to obtain some statistics concerning the textbooks that are used for the 2012 academic year. The original table (See Appendix) shows a list of 29 private middle schools and a list of textbooks used for

public middle schools within the four wards. Because Hōsengakuen (宝仙学園) middle school did not select a textbook, I have calculated the statistics used for the textbooks for 28 private middle schools within the fourth district. 


\begin{tabular}{l|l|ll}
\hline PUBLISHER & & \# OF BOOKS & $\%$ OF TOTAL \\
\hline TOKYO SHOSEKI & CONSISTENT & 8 & 28.571 \\
KYOIKU SHUPPAN & NEUTRAL & 3 & 10.714 \\
TEIKOKU SHOIN & NEUTRAL & 9 & 32.142 \\
IKUHŌSHA & DIVERGENT & 2 & 7.142 \\
SHIMIZU SHOIN & No DATA & 3 & 10.714 \\
NiHON BUNKYO & CONSISTENT & 3 & 10.714 \\
JIYUSHA & DiverGENT & 0 & 0 \\
\hline
\end{tabular}

Table 2. Adoption rate for private schools in Shinjuku, Shibuya, Nakano, and Suginami Source: Data adapted from Daiichi kyōkasho (See Appendix G).

As seen in the Table 2, both Atarashii shakai rekishi by Tokyo Shoseki and Shakaika chūgakusai no rekishi: Nihon no ayumi to sekai no ugoki by Teikokushoin have a strong representation within the district (28.5\% and $32.1 \%$ adoption rate, respectively), while the textbooks associated with the controversial Tsukuruai have a low adoption rate, such as Atarashii Nihon no rekishi by Ikuhōsha (7.1\% adoption rate), or have not been adopted, such as Atarashii rekishi kyōkasho by Jiyūsha. ${ }^{133}$ It should be noted that I was not able to acquire the Shimizu textbooks for unknown reasons - this textbook was not available at the textbook store in Tokyo or Kobe.

${ }^{133}$ Daiichi Kyōkasho, accessed December 13, 2012. http://daiichikyokasho.co.jp/price/index.html. 


\begin{tabular}{|c|c|}
\hline TOKYO WARD & TEXTBOOK \\
\hline SHINJUKU & TOKYO SHOSEKI \\
\hline SHIBUYA & TOKYO SHOSEKI \\
\hline NAKANO & TEIKOKUSHOIN \\
\hline SUGINAMI & KYŌIKUSHUPPAN \\
\hline
\end{tabular}

Table 3. Textbook adoption for public schools in four of Tokyo's Wards Source: Data adapted from Daiichi kyōkasho (See Appendix G).

Two of the four public middle school wards adopted Atarashii shakai rekishi by Tokyo Shoseki, while the other two adopted by Shakaika chūgakusai no rekishi: Nihon no ayumi to sekai no ugoki by Teikokushoin and Chūgaku shakai rekishi: Mirai no hiraku by Kyōikushuppan (see Table 3). An interesting observation from Table 3 shows that textbook adoptions for these public schools is compatible with the previous information concerning the process of adoptions in towns, cities, prefectures and municipalities. As previously stated, prefectural and municipal boards of education represent up to three cities or counties, which are made up of principals, teachers, and members of the board of education as well as others with experience in education and each school does not choose its own textbook. Although the number of the public schools within each ward is not available, it shows that public middle schools adopted the same textbook given that they are within the same ward. 
Based on the information provided from Daiichi kyōkasho, it can be deduced that the textbook with the least nationalistic portrayal concerning the Second Sino-Japanese War, Atarashii shakai rekishi by Tokyo Shoseki, has a strong adoption rate within the fourth district, with a majority of the adoption in private middle schools as well as within two of the four wards. The adoption rate of Atarashii shakai rekishi, within the fourth district of Tokyo, is consistent with the 2001 statistic (see Table 1) that shows that the history textbook by Tokyo Shoseki had a 51 percent adoption rate within Japan. Also based on the information provided by Daiichi kyōkasho, we can see that a neutral or somewhat nationalistic textbook, Shakaika chügakusai no rekishi: Nihon no ayumi to sekai no ugoki by Teikokushoin, also has a high percept of adoption with nine textbook adoptions within private middle schools and adoptions within one of the four wards. Although, Shakaika chügakusai no rekishi can be criticized for having some whitewashed portrayals, the information provided within the textbook is more harmonious (less whitewashed) and detailed than the textbooks that are associated with right-wing organizations.

Atarashii Nihon no rekishi by Ikuhōsha and Atarashii rekishi kyōkasho by Jiyūsha are textbooks that are associated with right-wing organizations and have a low to nonexistent adoption rate within the fourth district Tokyo schools. The adoption rates for Atarashii Nihon no rekishi and Atarashii rekishi kyōkasho are consistent with the low 2001 adoption rate of for Atarashii rekishi kyōkasho, whose textbook content is associated with both 2012 textbooks. Given these adoption rates in comparison to the statistics for 2001, the middle school history education consists of a liberal (least nationalistic) to neutral portrayal of Japan's involvement in the Second Sino-Japanese 
War, as the controversial textbooks continue to show low adoption rates. However, it is possible that the adoption of more controversial textbooks is growing, although assumingly marginally, because of the change in their portrayal since 2005, which contains less whitewashing than their earlier 2001 version. Nevertheless, further research is required to deduce the adoption process and rates in a large municipality such as Tokyo, as well as the current adoption rates for history textbooks within Japan as a whole.

\section{CONCLUSION}

\section{A. Future of Sino-Japanese Relations}

While there have been frequent talks about the need to settle the past and come to a mutual understanding, a series of diplomatic incidents, such as the prime ministerial visits to the controversial Yasukuni Shrine, disagreements over the wording of apologies and the claims to uninhabited islands in the East China Sea, have continued to disrupt the relationship and highlight how far both sides still have to go to achieve a reconciliation. The future stability of East Asia lies in the hands of China, Japan and South Korea. However, recent territorial disputes and statements by Japanese officials continue to strain relations between these neighboring nations and have pushed the Japanese middle school history textbook controversy into the background since 2006 .

On January 2, 2013, reelected Prime Minister Abe Shinzo stated that he plans to revise Japan's apologies for its wartime aggression during World War II, starting with apologies issued to China and South Korea concerning women who were used as comfort women by Prime Minister Murayama Tomiichi, who was at the time head of the Social Democratic Party of Japan. In 1995, Tomiichi acknowledged that the Japanese Imperial 
Forces "through [Japan's] colonial rule and invasion...caused tremendous damage and suffering to the people of many countries, particularly those of Asian nations." ${ }^{134}$

According the Sankei Shimbun, a right-leaning media outlet, Prime Minister Abe stated that he wanted to replace the apology with a "forward looking statement" because, as stated in a previous term, there was no evidence that women specifically were coerced or forced into sexual slavery for the Japanese Imperial Army. ${ }^{135}$ However, at a news conference, the Chief Cabinet Secretary, Yoshihide Suga clarified that the Prime Minister would adhere to the 1995 Murayama apology, but may revise the 1993 statement by Chief Cabinet Secretary Yōhei Kōno, who specifically apologized for the use of comfort women.

These controversial statements by Prime Minister Abe concerning World War II atrocities could not have come at a worse time, as both Japan and China have been the most active, from a military standpoint, in the Sea of Japan and the East China Sea because of the dispute over the Senkaku/Diaoyu Islands, since World War II. China, who traces their claim to the islands since 1403 and Japan, whose claim of the island is acknowledges acknowledged by the United States even though the Potsdam Treaty obligated Japan to surrender their claim to all imperial territories, have both sent fighter jets to investigate the area surrounding the islands. Even though Chinese fighter jets have entered the Japan Self Defense Force Air Identity Zone, this is a mission that has not

134 "Statement by Prime Minister Tomiichi Yurayama on the Occasion of the $50^{\text {th }}$ Anniversary of the War's End," Ministry of Foreign Affairs of Japan, August 15, 1995. http://www.mofa.go.jp/announce/press/pm/murayama/9508.html.

135 “Another Attempt to Deny Japan's History" The New York Times, Jan. 2, 2013. http://www.nytimes.com/2013/01/03/opinion/another-attempt-to-deny-japanshistory.html?_r=0. 
violated international law nor entered Japan's official airspace. However, despite the economic relationship, the increase of military presence could lead to an armed military conflict.

On January 28, 2012, in order to spread awareness concerning the nationalistic ideas held by key conservatives and the changes they wish to make in Japanese education, Children and Textbook Japan Network 21 prepared a list of the various Diet groups in which the members of the current Abe Cabinet belong. On the basis of this report, nine Diet members, currently $47.4 \%$ of cabinet members, are also members of the Nippon no zento to rekishi kyokasho wo kangaeru giin no kai (Diet Member Group for Considering Japan's Future and History Textbooks 日本の前途と歴史教科書を考える 議員の会). In 2008, the textbook Diet group conducted an investigation regarding the Nanjing Massacre and stated the that current U.S. films and documentaries concerning the tragedy "is not only an insult to the honor and dignity of past Japanese but at present and into the future puts forward the idea that the Japanese are the cruelest race in the world." ${ }^{136}$

The members include: Prime Minister Shinzo Abe, who serves as the main advisor for the Diet group; Shindo Yoshitaka, Minister of International Affairs and Communication; Kishida Fumino, Minister of Foreign Affairs; Nemoto Takami, Head of the Reconstruction Agency; Furuya Keiji, Commissioner for National Public Safety; Amari Akira, Minister of State for Economic and Fiscal Policy, who is also the Assistant Head of General Affairs for the textbook Diet group; Inada Tomoni, Minster of State for

${ }^{136}$ Children and Textbooks Japan Network 21, "The Abe Cabinet- An Ideological Freak Down, January 28, 2013," in The Asia-Pacific Journal: Japan Focus, trans. Matthew Penney. 
Regulatory Reform; and Suga Yoshihide, Chief Cabinet Secretary. Therefore, given the interest of Diet members and their participation in Nippon no zento to rekishi kyokasho wo kangaeru giin no kai, Children and Textbook Japan Network 21 stated that there will be a reemergence of the textbook controversy in the future.

In March of 2013, MEXT approved two geography textbooks and six of seven textbooks on politics and economics for high school that describes the Senkaku/Diaoyu Islands and Takeshima/Dokdo Islands as Japanese. The approval of the textbook were met with protest as Hong Lei, Chinese Foreign Ministry spokesman, stated, "We hope the Japanese side faces up to history and reality, corrects mistakes and takes concrete steps for improvement in bilateral relations" ${ }^{" 137}$ A spokes person for South Korea also stated "[Seoul] strongly protest against Japan for not looking squarely at history and having approved textbooks containing content that evades its responsibility, and we demand a correction of such textbooks." ${ }^{138}$ Given the remarkes from both China and South Korea, it is possible that the focus within the textbook controversy will move away from Nanjing and will focus on current issues, such as the Senkaku/Diaoyu and Tashima/Dokdo Islands.

\section{B. The History Textbook Controversy}

Within this study, I have explored Sino-Japanese Relations through the history textbook controversy to showcase unresolved historical issues that continue to cause

\footnotetext{
137 "Most New High School Textbooks describe Takeshima, Senkaku Islands as Japanese," Japan Times, last modified March 27, 2013, http:/www.japantimes.co.jp/news/2013/03/27/national/most-new-high-school-textbooksdescribe-takeshima-senkaku-islands-as-japanese/\#.UWILIb_iOXI.

138 Ibid.
} 
political disputes and currently harm relations between China and Japan. My analysis also introduced the historical accounts and eyewitness reports during the Second SinoJapanese War, specifically the Nanjing Massacre by John Rabe, a member of the National Socialist German Workers' Party who led and organized the International Committee for the Nanjing Safety Zone, and Wilhelmina "Minnie" Vautrin and Tsen Shui-feng, who established the Ginglin Women's College prior to the war. I compared these accounts to the portrayals found in various Japanese middle school history textbooks. The analysis was necessary not only to understand the victim/victimizer roles of China and Japan, but also to understand the deep-rooted sentiments of China toward Japan.

As stated within the hypotheses, the publishers of the history textbooks portray World War II atrocities in the final version of their history textbooks, but the Ministry of Education and textbook regulation councils (who are sometimes formed with members of political parties, such as the Liberal Democratic Party) regulate the textbooks, adjusting historical inaccuracies since the post-war era. According to Sugimoto Yoshio, the education system in Japan is characterized by a high degree of domination and centralization by the national government. He states that although the Japanese education was democratized and seemingly decentralized after the Second World War, "the postwar liberalization process never overturned the dominance of the state in the management of schools." ${ }^{139}$ Therefore, MEXT has developed the education system through intervention, as it controls the tone of all textbooks, supervises the national curricula, and also has

\footnotetext{
${ }^{139}$ Yoshio Sugimoto, Introduction to Japanese Society (Cambridge: Cambridge University Press, 2010), 128.
} 
considerable power over the administration of universities. The concentration of power by MEXT as well as its "political and ideological standpoint has provoked a heated controversy throughout the second half of the twentieth century."

Sugimoto also states that there is a lack of transparency between Japan's three sectors, big business, parliament and the national bureaucracy, who are within a threeway rivalry. For example, the public bureaucracy gathers information, and drafts policies for political circles, while political circles provide legislation and zoku (political activist) influence. Zoku parliamentarians, who are also LDP politicians, form special interest groups and are said to "exercise political influence over the process of government and bureaucracies policy formation." ${ }^{, 141}$ This influence over the process of government policy formation can been seen within the textbook selection process as political parties, such as the LDP work with right-wing organizations, such as Tsukurukai, either create or endorse history textbooks, such as Atarashii rekishi kyōkasho. However, left-wing organizations challenge the Ministry of Education and ring-wing groups by either boycotting or lobbying against the use of nationalistic textbooks.

My study also looked into how current textbooks disseminate World War II atrocities, specifically the Marco Polo Bridge Incident, which started the Second SinoJapanese War, the highly controversial Nanjing Massacre, and the use of comfort women. This was conducted through a syntactical analysis, by utilizing my own translations of key terms and phrases that are either included or left out of these textbooks.

\footnotetext{
${ }^{140}$ Ibid., 129-129.

${ }^{141}$ Ibid., 224.
} 
Within the translations, I have given examples showing that the portrayal of World War II-related atrocities can vary between different publishing companies. However, the majority of the textbooks adjust the wording to defend the actions of the Japanese Imperial Army during the Second Sino-Japanese War. The textbooks seem to justify, from a military standpoint, the actions taken towards China, by either making China the aggressor or stating that the massacre in Nanjing occurred during the invasion of the city and not after its defeat. The textbooks also fail to criticize any individual or organization, as the majority of the textbooks conclude that Nanjing was only internationally criticized, and that the people of Japan did not know of the atrocities until the Tokyo Trials. Moreover, the mentioning of comfort women has also been removed from the textbooks.

Conversely, some history textbooks portray a satisfyingly detailed (based on the size of the textbooks) and accurate account of the atrocities, by mentioning the situation in China prior to Japan's invasion and stating the more research is needed to have a definitive answer for the number of civilians that were killed during the Nanjing Massacre. The implication of the Japanese middle school history textbook is that the nationalist textbooks whitewash information and other textbooks that are not supported by right-wing groups provide more detail and give a neutral portrayal of the atrocities. For example, in the Teikokushoin textbook, the controversial wording of "advance" is used, but the mention of Nanjing is referred to as the Nanjing Massacre instead of the Nanjing Incident. Therefore, it is up to the publisher to provide the information within the textbook, but the information also becomes watered down due to the authorization regulations and the process of textbook committee and MEXT. However, in light of the 
controversy, even content within the right-wing supported textbooks have changed, as the 2001 Atarashii rekishi kyōkasho differed from the 2012 Atarashii rekishi kyōkasho. Furthermore, the publishing company Fusōsha, which published the 2001 and 2005 Atarashii rekishi kyokkasho, has dropped out of the textbook publishing industry all together. Therefore, although MEXT has an important role in the textbook screening process and have also been criticized for association with right-wing groups, the portrayals within the textbooks, in general, were not as divergent as what has been lead to believe in the past.

Looking into the degree of adoption of past and current Japanese textbooks within the primary and secondary academic system confirmed that the more nationalistic and controversial textbooks have a low adoption rate within the school system. Nevertheless, it should be noted that Japan is not exclusive in glossing over or whitewashing history in their textbooks, as all nations have a preference to their own historical view of the past reflects multiple perspectives. ${ }^{142}$ Moreover, organizations, such as the Japan's Teachers Union, and Children and Textbook Japan 21, have brought awareness to the textbook controversy, causing government agencies, like the Ministry of Foreign Affairs to react.

The implication of this thesis is to assist others in understanding World War II history, specifically the invasion of China and the Nanjing Massacre, and to notice the victim/victimizer roles of China and Japan. Although many scholars have researched various aspects of Sino-Japanese relations, further study of Sino-Japanese relations and, more specifically, the Japanese history textbook controversy is necessary to grasp the role

\footnotetext{
${ }^{142}$ This is in regards to the quote by Robert Evans: "There are three sides to every story yours, mine, and the truth."
} 
of MEXT, right-/left-wing organizations, and class instruction at the ground level. Therefore, those who have an interest in the history textbook controversy and plan to study or teach in Japan can utilize this information to conduct further research. Moreover, as new history textbooks are approved by MEXT, their translations into various languages is vital to see the evolution of the content within the history textbooks in order perceive their adoption rates and, specifically, the success of the nationalistic textbooks, such as Atarashii rekishi kyōkasho, as well as notice as to whether or not the textbooks continue to spark debates and protest in neighboring countries.

Minnie Vautrin's words about the future of Sino-Japanese relations were both prescient and troubling:

From a military point of view, the taking of Nanking my be considered a victory for the Japanese army, but judging it from the moral law it is a defeat and a national disgrace, which will hinder cooperation and friendship with China for years to come, and forever lose her the respect of those living in Nanking today. If only the thoughtful people in Japan could know what is happening in Nanking. ${ }^{143}$

${ }^{143}$ Vautrin and Tsen, The Undaunted Women of Nanking, 41. 


\section{LIST OF REFERENCES}

"Another Attempt to Deny Japan's History." The New York Times. Last modified January. 2, 2013. http:/www.nytimes.com/2013/01/03/opinion/another-attemptto-deny-japans-history.html?_r=0.

Atarashii nihon no reskishi. Japan: Ikuhōsha, 2011.

Atarashii rekishi kyōkasho. Japan: Fusōsha, 2001.

Atarashii shakai rekishi. Japan: Tokyo Shoseki, 2012.

Barnard, Christopher. "Isolating Knowledge of the Unpleasant: The Rape of Nanking in Japanese High-School Textbooks." British Journal of Sociology of Education 22, no. 4 (2001): 519-530.

BBC News. "Sex Slaves put on Trial”, last modified December 200, accessed January 13, 2013, http://newsbbc.co.uk/2/hi/asia-pacific/1061599.stm.

Brook, Timothy. "The Tokyo Judgment and the Rape of Nanking." The Journal of Asian Studies 60, no 3 (2001): 673-700.

Brownmiller, Susan. Against our Will: Men, Women and Rape. New York: Ballantine Books, 1993.

Bukh, Alexander. "Japan's History Textbook Debate: National Identity in Narratives of Victimhood and Victimization.” Asian Survey 47, no. 5 (2007): 683-707.

Caiger, John. "Ienaga Saburō and the First Postwar Japanese History Textbook." Modern Asian Studies 3, no. 1 (1969): 1-16.

Clancey, Patrick. "The IMTFE Judgment." http://www.ibiblio.org/hyperwar/PTO/IMTFE/index.html.

Chang, Iris. The Rape of Nanking: the Forgotten Holocaust of World War Two. New York: Penguin Group.,1997.

Children and Textbooks Japan Network 21. "The Abe Cabinet- An Ideological Freak Down, January 28, 2013." In The Asia-Pacific Journal: Japan Focus. Translated by Matthew Penney.

Chūgaku shakai rekishi, Japan: Nihonbun Kyōshuppan, 2012.

Chūgaku shakai rekishi: Mirai no hiraku, Japan: Kyōikushuppan, 2012. 
Chūgaku shakai: Atarashii rekishi kyōkasho, Japan: Jiyūsha, 2012.

Chūgakusei no rekishi: Nihon no ayumi to sekai no ugoki, Japan: Teikokushoin, 2012.

Conrad, Sebastian. "Entangled Memories: Versions of the Past in Germany and Japan, 1945-2001." Journal of Contemporary History 38, no. 1 (2003): 85-90.

Cryer, Robert and Neil Boister, eds. Documents on the Tokyo International Military Tribunal: Charter, Indictment and Judgments. New York: Oxford University Press, 2008.

Daiichi Kyōkasho. Accessed December 13, 2012.

http://daiichikyokasho.co.jp/price/index.html.

Deng, Yong. "Chinese Relations with Japan: Implications for Asia-Pacific Regionalism." Public Affairs 70, no. 3 (1997): 373-391.

Duke, Benjamin. "The Japanese Supreme Court and Governance of Education." Pacific Affairs 10, no. 1 (1980): 77.

Hilpert, Hanns Gunther and Rene Haak. Japan and china: Cooperation, Competition and Conflict. New York: Palgrave, 2002.

Hirofumi, Hayashi "Disputes in Japan over the Japanese Military 'Comfort Women' System and Its Perception in History." Annals of the American Academy of Poltical and Social Science 617 (2008): 123-132.

Hiroshi, Mitani, “Japan's History Textbook System and Its Controversies." In Towards a History Beyond Borders. Cambridge: Harvard University Press, 2012).

Horio, Teruhisa. Educational Thought and Ideology in Modern Japan: State Authority and Intellectual Freedom. Tokyo: University of Tokyo Press, 1988.

Howe, Christopher, ed. China and Japan: History, Trends and Prospects. New York: Oxford University Press, 1996.

Hsiung, James C., ed. China and Japan at Odds: Deciphering the Perpectual Conflict. New York: Palgrave Macmillan, 2007.

Huntsberry, Randy “'Suffering History': The Textbook Trial of Ienaga Saburō.” Journal of the American Academy of Religion 44.2 (1976): 239-254.

"Improving the Textbook Authorization System." Ministry of Education, Culture, Sports, Science and Technology. Last modified November 30, 2011. 
http://www.mext.go.jp/b_menu/hakusho/html/hpae199401/hpae199401_2_092.ht $\mathrm{ml}$.

“International Military Tribunal for the Far East.” International Organization 3, no. 1 (1949): 184-186.

Jeans, Roger B. "Victims or Victimizers? Museums, Textbooks and the War Debate in Contemporary Japan.” The Journal of Military History 69, no. 1 (2005): 149-195.

Johnson, Chalmers. "The Patterns of Japanese Relations with China: 1952-1982." Public Affairs 59 no. 3 (1986): 402-428.

Ministry of Foreign Affairs, "How a Textbook Becomes Part of a School Curriculum." Last Modified June 2005, http://www.mofa.go.jp/policy/education/textbooks/overview-1.html.

"Most New High School Textbooks describe Takeshima, Senkaku Islands as Japanese." Japan Times. Last modified March 27, 2013, http://www.japantimes.co.jp/news/2013/03/27/national/most-new-high-schooltextbooks-describe-takeshima-senkaku-islands-as-japanese/\#.UWILIb_iOXI.

Pingel, Falk "Can Truth Be Negotiated? History Textbook Revision as a Means to Reconciliation." Annals of the American Academy of Political and Social Science 617 (2008): 181-198.

Pyle, Kenneth B. "Japan Besieged: The Textbook Controversy: Introduction" Journal of Japanese Studies 9, no. 2 (1983): 297-300.

Rabe, John. The Good German of Nanking: The Diaries of John Rabe. Edited by Erwin Wickert, translated by John E. Woods. London: Little, Brown and Company, 1999.

Reinhold, Christine I. Studying the Enemy: Japan Hands in Republican China and their Quest for National Identity. New York: Routeledge, 2001

Rose, Caroline. Interpreting History in Sino-Japanese Relations: A Case Study in Poltiical Decision-making. New York: Routledge, 1998.

- Sino-Japanese Relations: Facing the Past, Looking to the Future? New York: RoutledgeCurzon, 2005.

Rozman, Gilbert. U.S. Leadership, History, and Bilaterial Relations in Northeast Asia. UK: Cambridge University Press, 2010.

Saburō, Ienaga. Japan's Past and Japan's Future: One Historian's Odyssey. New York: 
Rowman and Littlefield Publishers, Inc., 2001.

- The Pacific War, 1931-1945: A Critical Perspective on Japan's Role in World War II. New York: Random House Inc., 1978.

Schneider, Claudia, "The Japanese History Textbook Controversy in East Asian Perspective." Annals of the American Academy of Political and Social Science 617 (2008): 107-122.

Seddon, Terri. "Politics and Curriculum: A Case Study of the Japanese History Textbook Dispute." British Journal of Sociology 8, no. 2 (1982): 213-226.

Shudo, Higashinakano. The Nanking Massacre: Fact Versus Fiction A Historian's Quest for the Truth. Tokyo: Sekai Shūpan, 2005.

Soderberg, Marie., ed. Chinese-Japanese Relations in the Twenty-First Century: Complemenntarity and Conflict. London: Routledge, 2002.

"Statement by Prime Minister Tomiichi Yurayama on the Occasion of the $50^{\text {th }}$ Anniversary of the War's End." Ministry of Foreign Affairs of Japan. Last modified August 15, 1995. http://www.mofa.go.jp/announce/press/pm/murayama/9508.html.

Stevenson, Harold W. "Japanese Elementary School Education." The Elementary School Journal 92, no. 1 (1991): 109-120.

Sugimoto, Yoshio. Introduction to Japanese Society. Cambridge: Cambridge University Press, 2010.

Vautrin, Wilhelmina "Minnie" and Tsen Shui-fang. The Undaunted Women of Nanking: The Wartime Diaries of Minnie and Tsen Shui-fang. Edited and Translated by Hua-ling $\mathrm{Hu}$ and Zhang Lian-hong. Illinois: Southern Illinois University Press, 2010 .

Wakabayashi, Bob Tadashi. "The Nanking 100-Man Killing Contest Debate: War Guild amid Fabricated Illusions: 1971-1975." Journal of Japanese Studies 26, no. 2 (2000): 307-340.

Wan, Ming. Sino-Japan Relations: Interaction, Logic, and Transformation. Washington, D.C.: Woodrow Wilson Center Press, 2006.

Yoshida, Takashi. The making of the "Rape of Nanjing:" History and Memory in Japan, China and the United States. Oxford University Press, 2006. 


\section{APPENDICES \\ APPENDIX A}

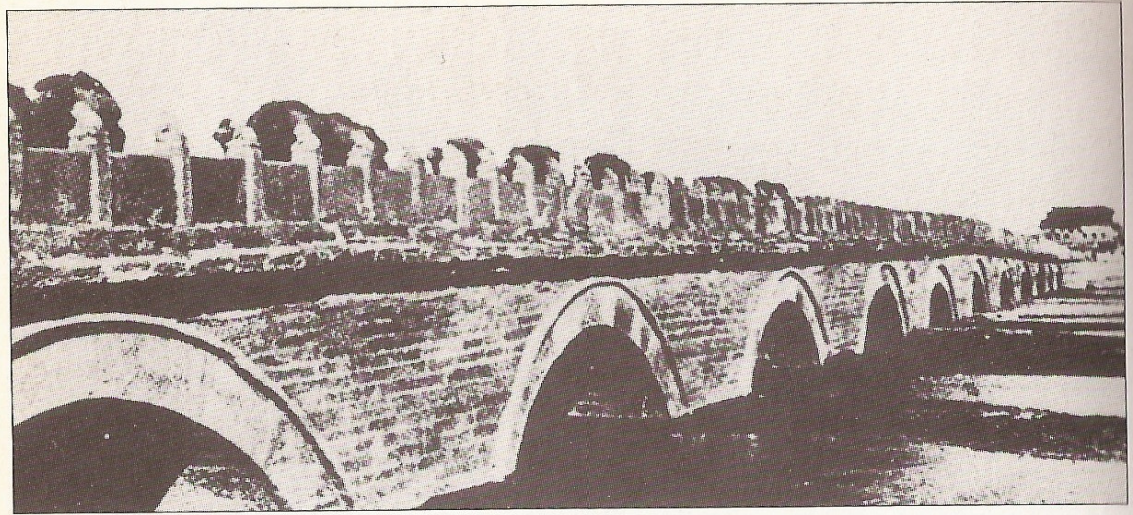

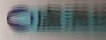

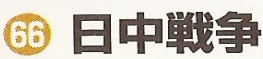

盧溝橋における 日中衝突

険東う簐など現地の日本軍は，満州国を維 し，ブロック経済圈を建設するために, 接する華北地域に獎介石政権の支配のおよばない親日政権青 くるなどして，中国側との緊張が高まっていた。また， 月本 北京周辺に 4000 人の駐屯軍を配置していた。これは義和付事价 のあと，他の列強諸国と同様に中国と結んだ条約に基づくも であった。1937(昭和12)年 7 月 7 日夜，北京郊外の盧溝槜 演習していた日本軍に向けて何者かが発砲する事件がおこ。 翌朝には，中国の国民党軍との間で戦闘状態になった(盧溝橋事 件)。現地解決がはかられたが，やがて日本側も大規模な派り 命じ，国民党政府もただちに動員令を発した。以後 8 年間に たって日中戦争が継続した。

同年 8 月，外国の権益が集中する芒海で，二人の日本人将! が射殺される事件がおこり，これをきっかけに日中間の全面部 争が始まった。日本軍は国民党政府の首都南京を落とせば蔣引 石は降伏すると考え，12月，南京を占領した(このとき，日本牛 によって民衆にも多数の死傷者が出た。南京事件)。しかし，䔮 


\section{APPENDIX B}

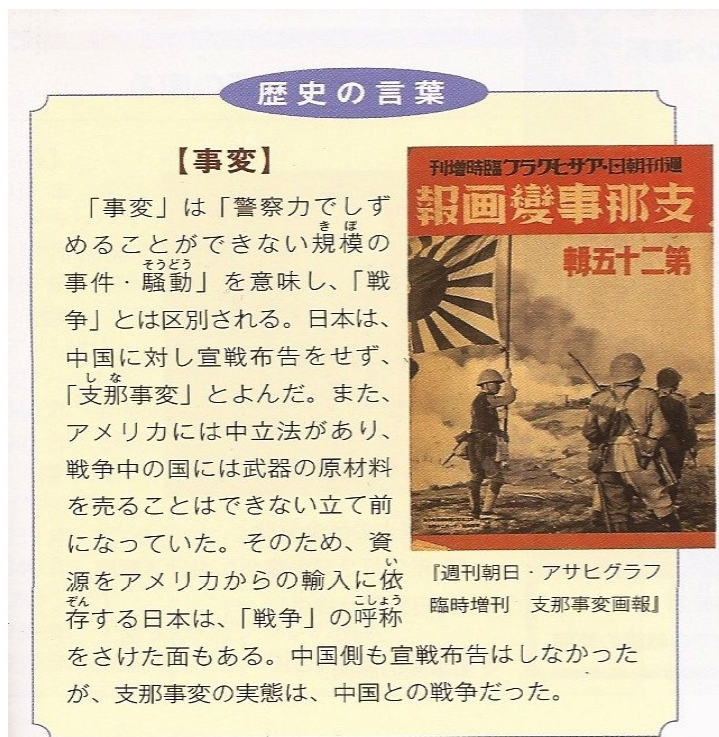

日中戦争の始まり

いっぽう、日本軍は満州国の維持や資源

確保のために、隣接する華北地方に親

日政権をつくるなどして、中国側との緊張が高まった。ま た、日本は義和団事件のあと、他の列強諸国と同様に中国

5 と結んだ条約によって、北京周辺に 5000 人の軍隊を駐屯 させていた。

1937 (昭和 12$)$ 年 7 月 7 日夜, 北京郊外の盧溝橋で、 演習していた日本軍に向けて何者かが発砲する事件がおき、 翌日には、中国軍と戦闘状態になった (盧溝橋事件)。事 件そのものは小規模で、現地解決がはかられたが、日本は 派兵を決定し、中国側も動員令を発した。その後も戦闘は 絶えず、翌月には、外国の権益が集中し各国の租界がある 上海で、二人の日本人将兵が射殺される事件がおこり、中 国軍が日本人居留区を包囲した。日本は日本人保護のため 派兵した。こうして日中戦争（日本は当時「支那事変」と よんだ）が始まり、拡大した。

日本軍は国民政府の首都南京を落とせば蒋介石は降伏す ると考え, 12 月, 南京を占領した。しかし, 蒋介石は奥 地の重慶に首都を移し，抗戦を続けた。
31937 年7月末には北 京東方の通州で、200人の 民間日本人が親日政権の兵隊 に惨殺される、通州事件がお こった。

4 中国軍はドイツの軍事指 導と武器援助を受け、強力な 軍隊に変貌していたが、日本 はそのことを軽視していた。 中国は見返りに、希少金属の タングステンをあたえて、ヒ トラーの軍備拡張を支えた。

5 南景告領の際に、日本軍 によって中国の軍民に多数の 死傷者が出た (南京事件)。

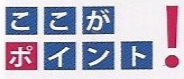

日中戦争開始の経過は? ? (1)西 安事件で、中国国内の二大政治 勢力の抗日方針が一致(2)盧溝橋 事件（日中戦争の始まり）(3日 中戦争の拡大(4)南京占領によっ ても戦争は終結せず長期化 


\section{APPENDIX C}

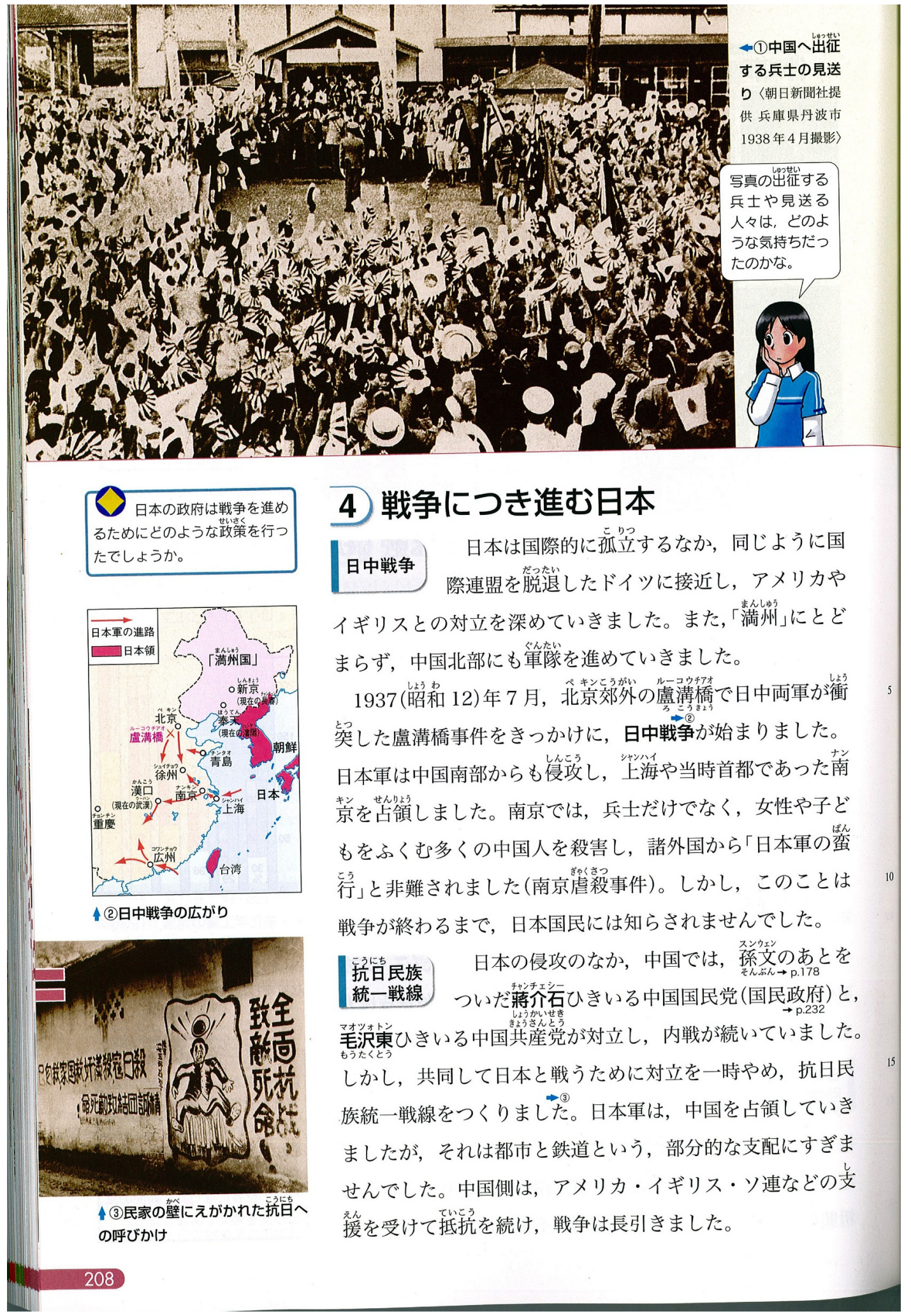




\section{APPENDIX D}
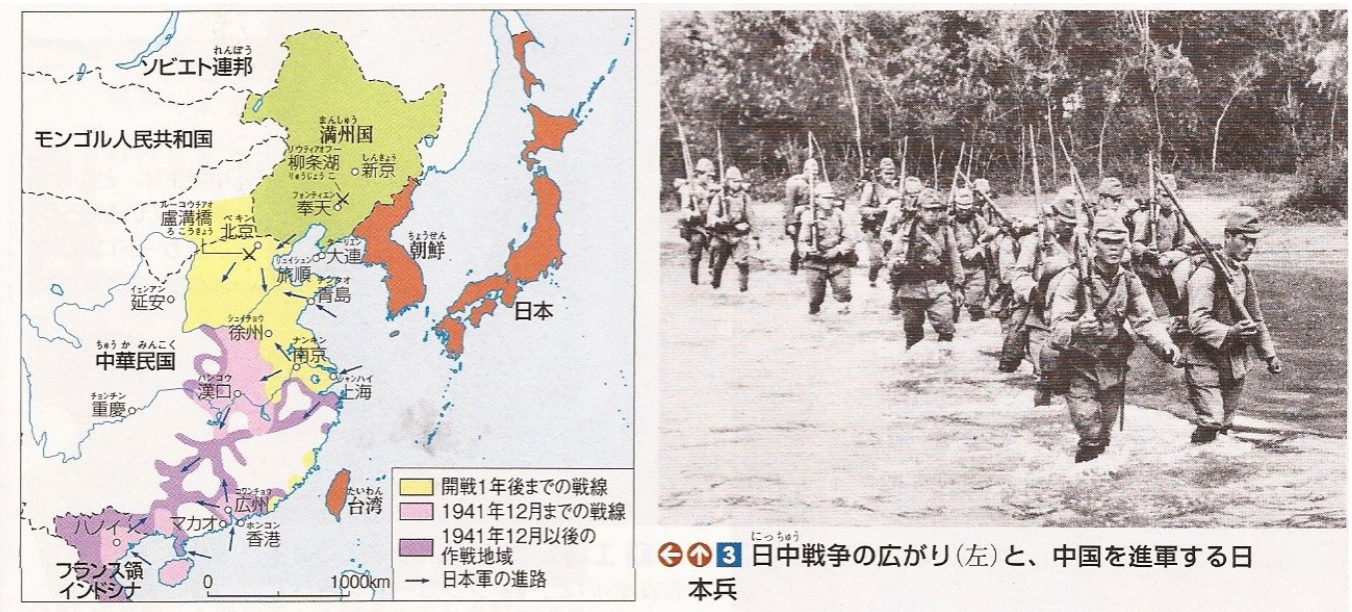

こうして, 軍国主義の動きが国内で高まるなか, 日本は, 簧 笙主義の勢力に符抗するという理由から，ファシズムを進める ドイツに接近し，1936年に日独防共協定を結びました。

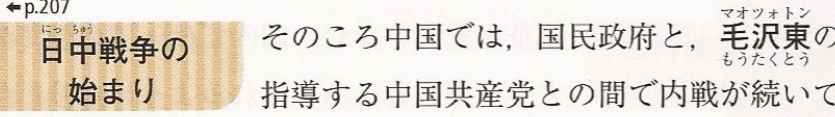
いました。根抛地を延安に移した共産党は, 国民政府に対し， 協力して日本に抵抗することを呼びかけ, 1936年, 内戦は停止 されました。そして, 中国は, 満州から華北へ勢力を拡大しょ うとする日本と，対立を深めるようになりました。

101937 年 7 月, 北京郊外の盧粠橋で、日本軍と中国軍の武力衝 突(盧溝橋事件)が起こったのをきっかけに，日中戦争が始まり ました。8月には上海にも蟬䉍が広がり，萱䇝布告のないまま に, 日本軍は次々に兵力を増強して戦線を拡大しました。12月 に告領した首都の南京では, 多数の捕虜や住民を殺害し, 国際 的な非難を受けました(南京事件)。

\section{長期化する戦争}

戦争が始まると, 国民政府は共産党と抗望 民族統一戦線を結成するとともに，首都を

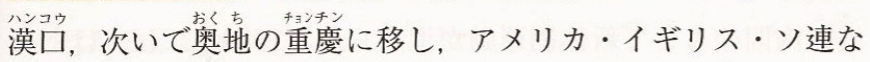
どの援助も受けて日本軍と戦いました。その間, 和平を実現し ようとする動きもありましたが, 近衛内閣は, それを自ら打ち 切ってしまいました。日本軍は, 重慶を爆撃し, 中国各地を占 領しましたが, 中国民衆のねばり強い抵抗により, 戦争は泥浆照 のような長期戦となっていきました。

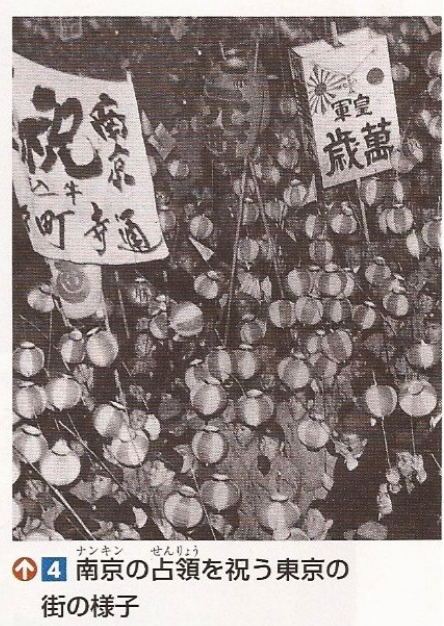

(1)この事件は, 当時の国民には 知らされず，戦後になって明らか にされました。

\section{䣄下ライ!}

四 五・一五事件と二・二 六事件の前後で, 日本の 政治や外交はどのように 変わったか説明しよう。 口 1936年にドイッで開 催された, ベルリンオリ ンピックについて調べて みよう。 


\section{APPENDIX E}

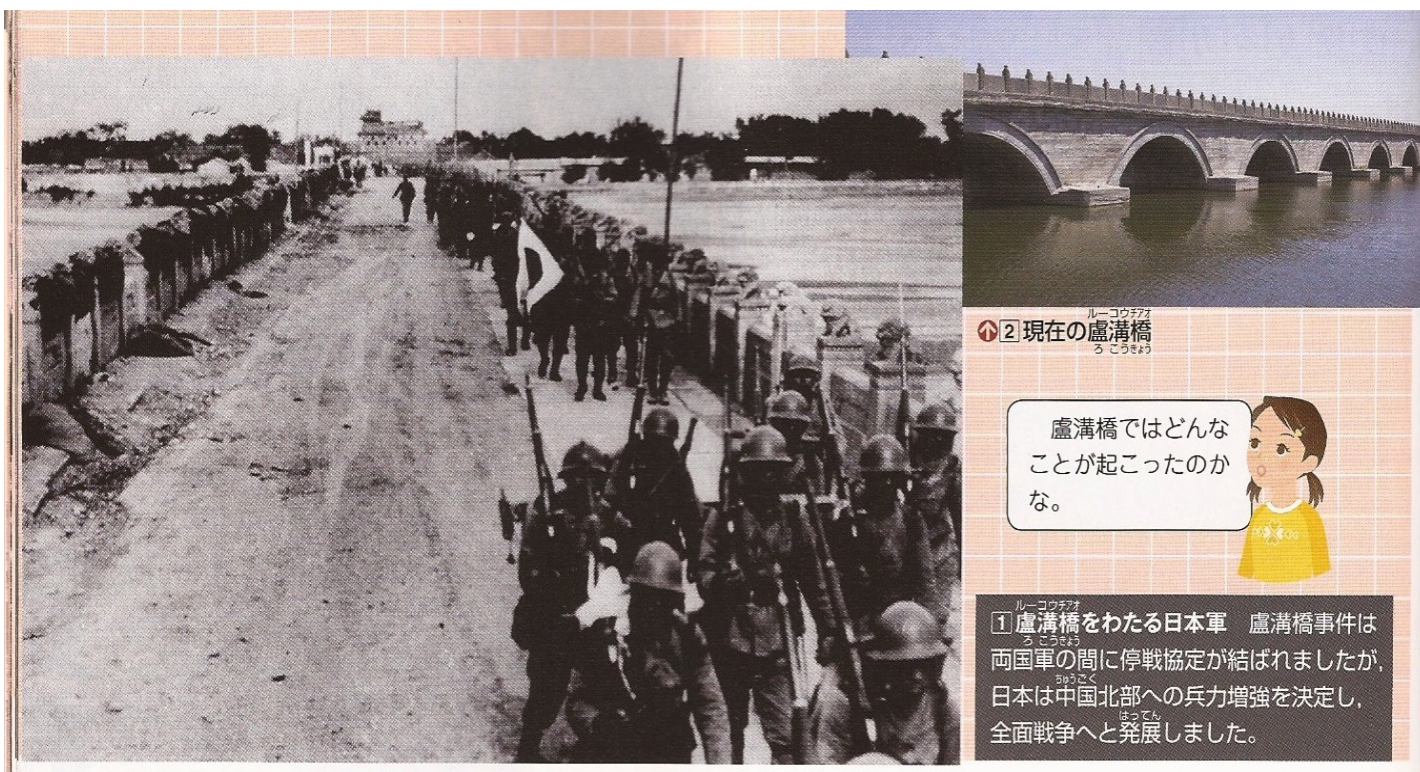

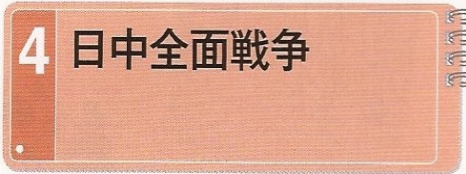

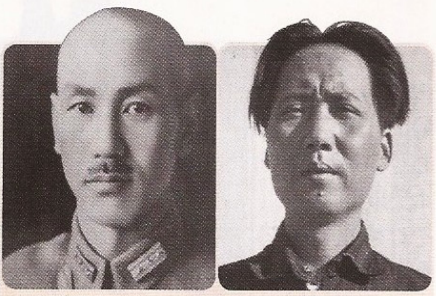

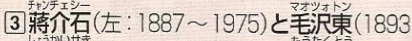
$\sim 1976$ )

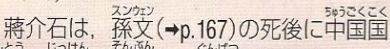

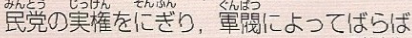
らに支配されていた中国を統一し，国民政 府主席となりました。毛沢東は, 1921年

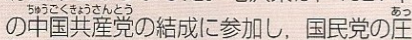
迫からのがれるための大移動(長征)の途中 で党の実権をにぎりました。

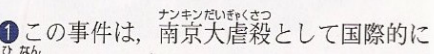
非難されましたが、日本の国民には知らさ れず, 戦後の極東国際染事裁判(東景裁判 ーp.227)で明らかにされました。被害著の数 については, さまざまな調査や研究が行わ れていますが，いまだに確定していません。

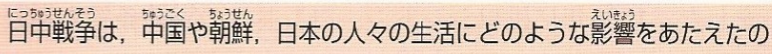
でしょうか。

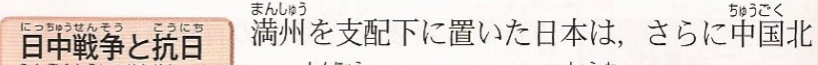
膂族統一戦線 部に侵人比しました。1937(昭和 12)年 7 月 7 日,

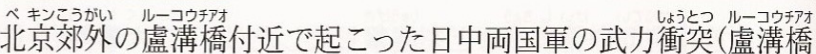
事件)をきっかけに，日中戦竞が始まりました。

中国では, 1927年の国民政府の樹立以来, 茴民㠰竟と共産党の 内戦が続いていましたが，日本の中国北部への侵入に対する抗音㚛 運動がもり上がる中, 毣沢梁を指導者とする共産党は, 協力して 日本に対抗しようと呼びかけ，国民党もこれに応じて，1937年 9 月に協力体制が実現し，抗日民族統一戦線が結成されました。

泥沼表化する戦争戦火は中国北部から中部に拡大し，日本軍は， 泥沼化する戦争 同年末に首都の南景を茣領しました。その過 程で，女性や子どもなど一㮽の人々や捕虜をふくむ多数の中国人

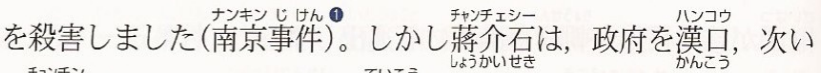
で䡤慶に移して, 日本軍への抵抗を続けました。

中国の民架暴の抗日意識はいっそう高まり, 日中戦争は全面戦争 に登登展し, 長期化していきました。日本は1940年に, 南京に新 政府を樹立させましたが，国民政府は，アメリカ，イギリスなど 


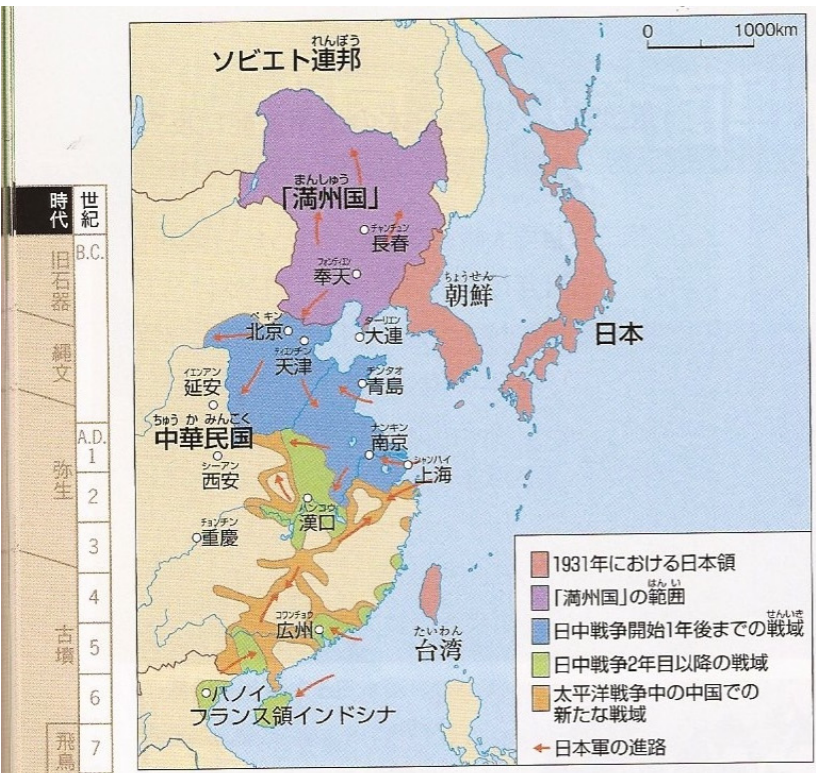

2

\section{日中全面戦争と戦時体制}

\section{年 できことと \\ 日本が, 策菄省に出兵する(翌年 日本軍が，満州の簐閥を爆殺する (世界恐慌) \\ 1931 満州事変が起こる \\ 1932 「満州国」の建国萱言 (立・的立事件) \\ 1933 \\ 1936 (日本が国際連盟を脱退) \\ 1937 (兰·水公事件) 日中戦争が始まる}

(2)昭和初期の 日中関係の動き

\section{(1)日本の中国侵略}

日本の軍部の予想と 翼なり, 戦争は長期化 していきました。

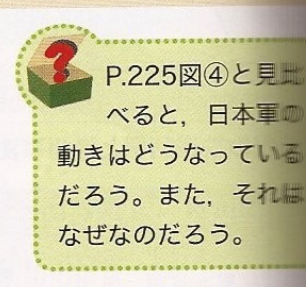

日本は, どうして中国と 学習課題 日本は, どうして中国し の全面的な戦争を始めだ 争が続くなか，国民のくらじ
うに変わっていったのだろう。
四日本軍は，華北(中国北部)の 鉄鉱石や石炭をねらい, この地 域を国民政府の支配から切りは なそうとしました。

2 義和団事件 $(\rightarrow$ P.190)を鎮圧 したときの清と連合国の取り決 めで, 日本も北京に軍隊を駐留 させていました。

消当時，この事件は日本国民に は知らされませんでした。戦後, 極東国際軍事裁鞛に当時の調査 資料が提出され，その後の研究 で，部隊や将兵の日記にもさま ざまな殺害の事例が記されてい ることがわかりました。ただし， 知られていない殺害がどれだけ あるのか, 全体像をどうとらえ ればよいのかなど, さらに研究 が必要な部分もあります。

\section{中国との} 全面戦争

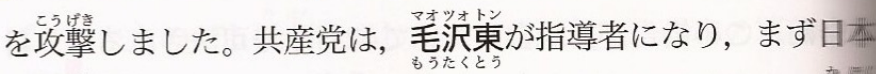
に抵抗することをよびかけました。いつぽう，日本軍は，華華 を勢力圈にしょうとして工作を進め, 北京駐留の部隊を増強す るなど, 中国との対立を強めていきました。

1937 (昭和12)年 7 月, 北京郊外の盧溝揞で, 日本軍と中国軍 が衝笑する事件が起こりました。現地では停戦協定が結ばれた にもかかわらず，この機会に勢力圈を広げようと考えた軍人も 多く, 戦火は上海に広がり, 管戦布告のないままに全面的な日 中戦争が始まりました。国民政府は, 共産党との戦いをやめて, 日本軍と戦うことを決めました。

日本軍は, 各地ではげしい抵抗にあいながらも戦線を広げ, 12月に苫領した首都南紊では, 捕虜のほか, 女性や子どもを含 む多数の住民を殺害しました(南京事件)。国民政府は, 首都を 漢口, 次いで奥地の重慶に移し, 抗戦を続けました。 
APPENDIX G

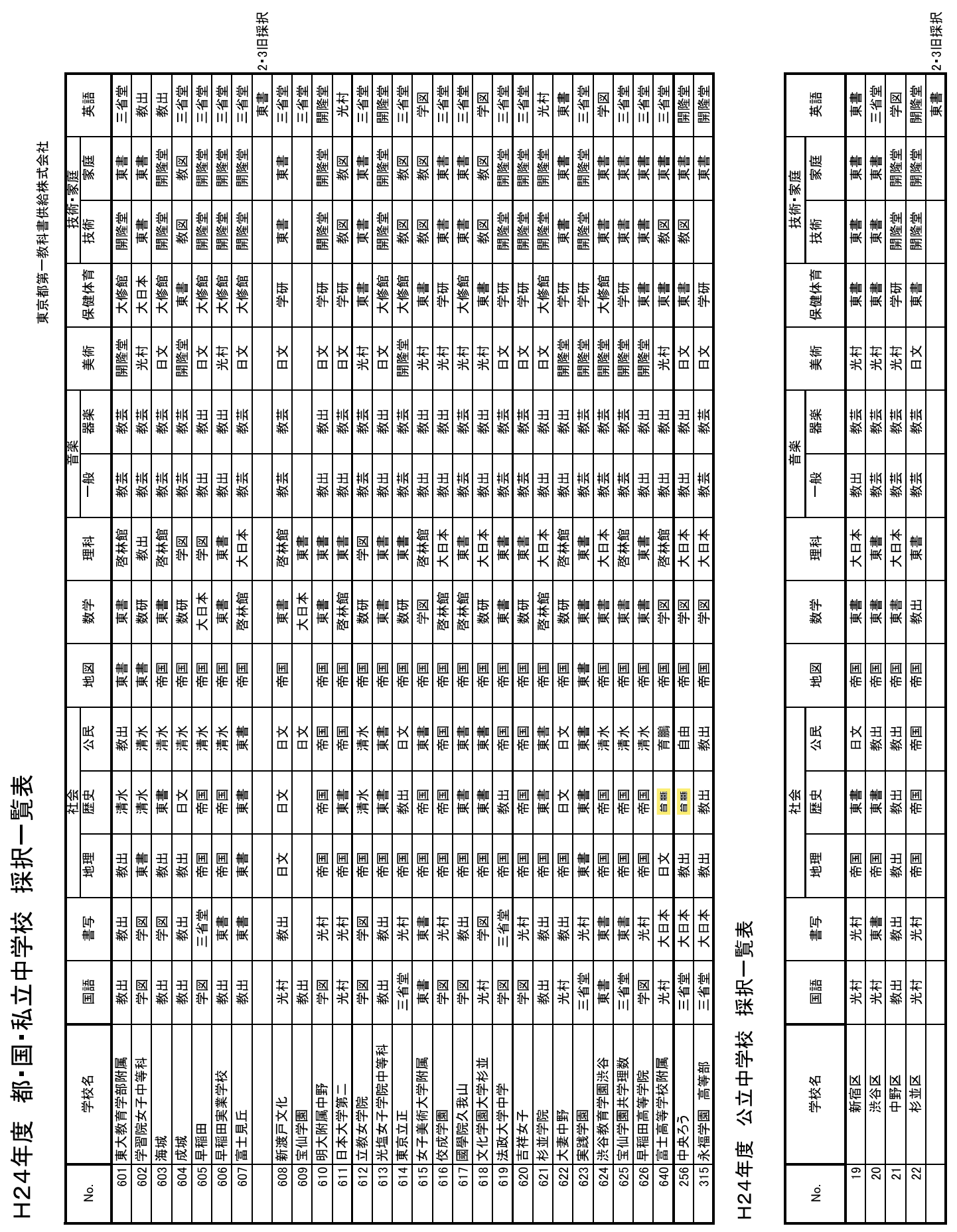

